\title{
Three Decades of Coastal Changes in Sindh, Pakistan (1989-2018): A Geospatial Assessment
}

\author{
Shamsa Kanwal ${ }^{1, *} \mathbb{(}$, Xiaoli Ding ${ }^{1}\left(\mathbb{D}\right.$, Muhammad Sajjad ${ }^{2,3}$ and Sawaid Abbas ${ }^{1}$ \\ 1 Department of Land Surveying and Geo-Informatics, The Hong Kong Polytechnic University, \\ Hong Kong, China; xl.ding@polyu.edu.hk (X.D.); sawaid.abbas@gmail.com (S.A.) \\ 2 Guy Carpenter Asia-Pacific Climate Impact Centre, School of Energy and Environment, \\ City University of Hong Kong, Hong Kong, China; mah.sajjad@hotmail.com \\ 3 Department of Civil and Environmental Engineering, Princeton University, Princeton, NJ 08542, USA \\ * Correspondence: shamsa.kanwal@connect.polyu.hk
}

Received: 3 November 2019; Accepted: 13 December 2019; Published: 18 December 2019

\begin{abstract}
Coastal erosion endangers millions living near-shore and puts coastal infrastructure at risk, particularly in low-lying deltaic coasts of developing nations. This study focuses on morphological changes along the $\sim 320-\mathrm{km}$-long Sindh coastline of Pakistan over past three decades. In this study, the Landsat images from 1989 to 2018 at an interval of 10 years are used to analyze the state of coastline erosion. For this purpose, well-known statistical approaches such as end point rate (EPR), least median of squares (LMS), and linear regression rate (LRR) are used to calculate the rates of coastline change. We analyze the erosion trend along with the underlying controlling variables of coastal change. Results show that most areas along the coastline have experienced noteworthy erosion during the study period. It is found that Karachi coastline experienced $2.43 \pm 0.45 \mathrm{~m} / \mathrm{yr}$ of erosion and $8.34 \pm 0.45 \mathrm{~m} / \mathrm{yr}$ of accretion, while erosion on the western and eastern sides of Indus River reached $12.5 \pm 0.55$ and $19.96 \pm 0.65 \mathrm{~m} / \mathrm{yr}$ on average, respectively. Coastal erosion is widespread along the entire coastline. However, the rate of erosion varies across the study area with a general trend of erosion increasing from west to east in the Indus Delta region (IDR), and the highest average erosion rate is $27.46 \mathrm{~m} / \mathrm{yr}$. The interdecadal change during 1989-1999, 1999-2009 and 2009-2018 periods depicted an increasing linear trend $\left(R^{2}=0.78\right)$ from Karachi to Indus River (IR) East zone. The spatial trend from west to east is positively correlated with mean sea level rise, which has increased from 1.1 to $1.9 \mathrm{~mm} /$ year, and negatively correlated with topographic slope, which is found to be decreasing eastward along the coastline. The findings necessitate appropriate actions and have important implications to better manage coastal areas in Pakistan in the wake of global climate change.
\end{abstract}

Keywords: coastal erosion; remote sensing; Landsat; Indus Delta region; geographic information system; DSAS

\section{Introduction}

Coastal degradation endangers millions living near-shore and puts coastal infrastructure at risk. Impacts of coastal erosion are often sudden, making it a major coastal hazard [1,2]. The situation is more appalling in low-lying deltaic regions in developing nations (such as Pakistan, Philippines, and Bangladesh), which are less prepared to cope with the risks. Some long-term environmental processes such as sea level rise (SLR) [3] and increasing intensity of short-term events, such as storm surge and coastal flooding [4], manifest themselves in the form of coastal morphological change and intensify coastal erosion [5]. The trends and rates of morphological change of the highly dynamic land-water transition interface, known as coastline, represent the summaries of various coast-influencing processes such as SLR and storm surges [6]. Anthropogenic activities are another major factor accelerating coastal 
erosion. Protecting coastal assets is costly, and the climate-change-inflicted financial losses are huge and sudden [7]. Coping with coastal degradation and erosion problems requires regular monitoring of coastline changes and the study of their impacts on social-ecological systems using contemporary methods and innovative tools [8-10]. The spatiotemporal coastline change can be used as a proxy to monitor the coastal environmental change. The assessment of long-term trends is also important to improve the understanding regarding coastal responses to rising sea levels [11].

Several methods are available to study coastal changes, such as topographic surveys, aerial photogrammetry, unmanned aerial systems (UAS), and global positioning system (GPS) surveys [12-15]. Although these methods have a higher spatial resolution for coastal assessment of short-term changes as well as long-term trends, they are labor-intensive and expensive for developing countries-particularly for large-scale assessments. In the wake of SLR and increasing flooding owing to global climate change and increasing anthropogenic pressures on coastal systems, it is imperative to track the coastline changes [5], particularly those bordering the developing and low-lying deltaic coasts, to take appropriate measures for their stability.

Various studies have shown propitious potential in effective coastline delineation and mapping of geomorphological changes for different conditions of the ecosystem using the approaches mentioned above. For example, several studies have been conducted in Bangladesh [8,16], Egypt [17,18] and different coasts of the Mediterranean Sea [10,19-21]. Similar studies have also been carried out in the Yellow River Delta [22] and the Pearl River Delta [23] in China. Notably, a few relevant studies have focused on studying coastline degradation and morphological changes, particularly erosion in the Indus River Delta region (IDR), Pakistan on a large scale [24-27].

About 20 million people and $40 \%$ of the industry of Pakistan are vulnerable to the effects of coastal erosion [27]. Few efforts have been made to assess the impacts of erosion along the $\sim 1000-\mathrm{km}-1$ long coastline in Pakistan. Studies carried out to assess erosion and accretion along the coastline of Pakistan [24,26-30] are, however, localized and small-scale in nature. For example, the IDR segment of the coastline was investigated by Ijaz et al. [26] in terms of the evolution of its major tidal creeks from 1979 to 2017, while the spatiotemporal variability of the barrier islands (BIs) offshore of the Sindh coast over 1974-2017 was studied by Waqas et al. [27]. None of the studies have provided information on the entire coastline.

This study investigates, for the first time, the morphological change along the entire $\sim 320-\mathrm{km}$-long Sindh coast of Pakistan. In this context, three decades (1989-2018) of remote sensing observation are used to examine as well as map the morphological change and the controlling factors. The authors do acknowledge the current limitations of the study. Similar to SLR and topographic variations, land submergence owning to ground subsidence could also reshape the coastline in low-lying areas. However, in Pakistan, no such effects have been accounted for the coastline changes. Results from this study would offer a new scientific basis for devising new policies and action plans for managing coastal areas in Pakistan.

\section{Area of Study}

The over $\sim 1000 \mathrm{~km}$ long coastline of Pakistan is divided into the Sindh coast and the Makran coast [27]. We focus on the $320 \mathrm{~km}$ long Sindh coast that includes the world's sixth largest deltaic region (i.e., IDR) and the Karachi coast, $250 \mathrm{~km}$ and $70 \mathrm{~km}$, respectively. The Sindh coast, particularly the Karachi region, has experienced a rapid urbanization and economic growth over the past few decades. The coastline starts from Cape Monze on the west and ends at the Indian border on the east [31]. The Karachi coast hosts two ports, a nuclear power plant, two fish harbors, two industrial estates, and a steel mill. The IDR coast is indented by a unique dendritic network of 17 major creeks and numerous minor creeks, a vast expanse of mudflats, swamps, and estuaries occupied by one of the most extensive arid mangrove forests in the world. The IDR wetlands are protected areas under international regulations of Ramsar Convention. The drastic reduction in freshwater and silt loads in the Indus River (IR) below the Kotri barrage has severely affected the hydrological processes in the 
river's lower reaches, causing degradation of the sixth largest delta of the world. The abrupt cut-down in the sediment load and water discharge to the Arabian Sea has increased the impact of waves and tides and impeded the growth of the mangroves, resulting in seawater intrusion and accelerated coastal erosion. The IR drains into the Arabian Sea at Khobar Creek [25], bisecting the deltaic region into two zones, IR West and IR East. Following Ijaz et al. [26], we also divide the Sindh coastline into three zones: Karachi, IR West, and IR East (Figure 1). Each of the coastal zones contains a varying number of administrative units (Table 1). We will not include the barrier islands (BIs) in the analysis as they are very localized features along the coastline.

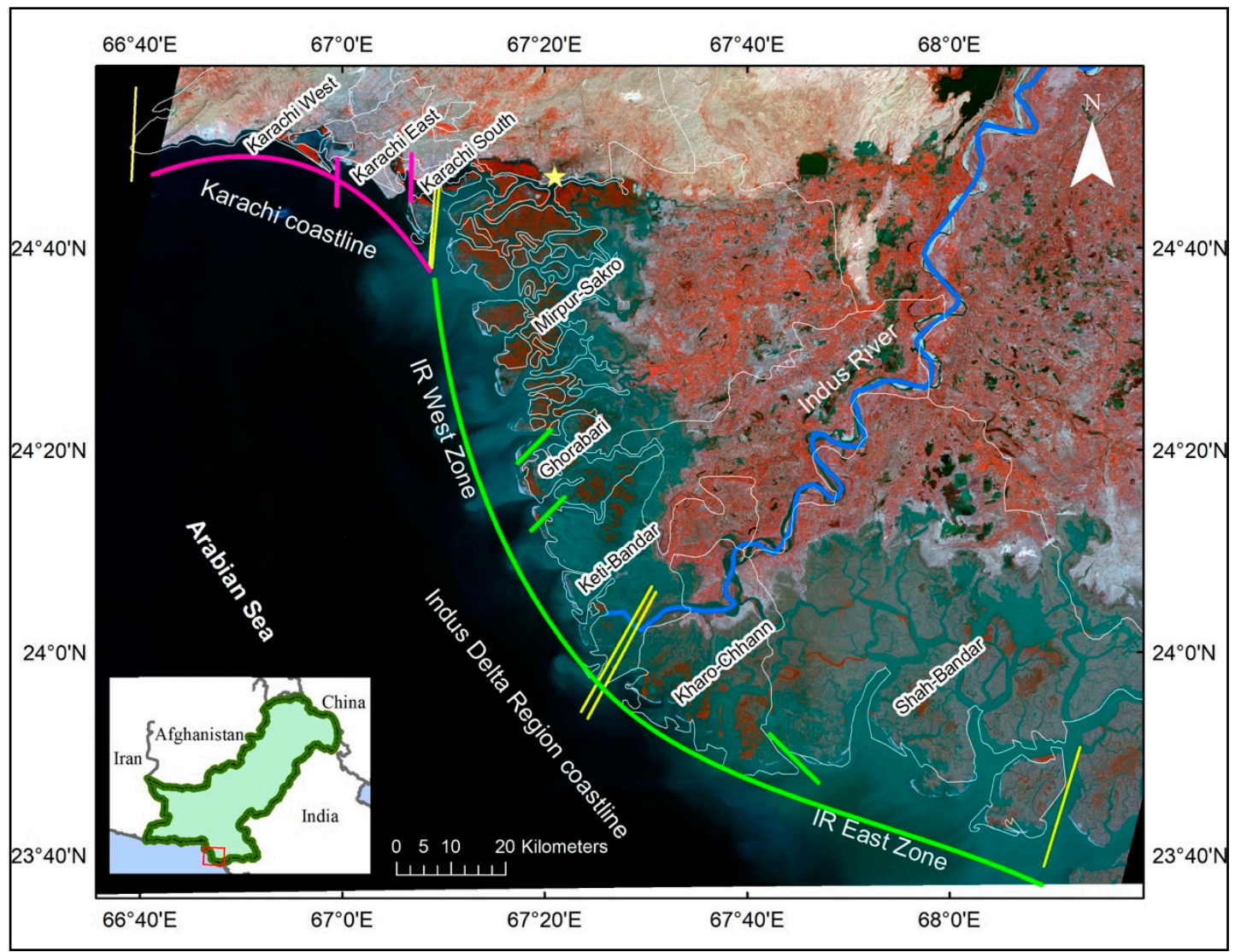

Figure 1. Location map of study area showing the Karachi (pink color) and the Indus Delta region (IDR) (green color) coastlines. The entire coastline is divided into different zones, Karachi, Indus River (IR) West, and IR East. Administrative boundaries (white lines) are overlaid on Landsat Operational Land Imager (OLI) false-color image (path 153, row 043; 2 March 2018). The inset shows the location of the Sindh coast (red rectangle).

Table 1. Administrative units within the three coastal zones.

\begin{tabular}{cc}
\hline Zone & Administrative Units \\
\hline Karachi & Karachi West, Karachi South, and Karachi East \\
IR West & Mirpur Sakro, Ghorabari, and Keti Bandar, located between Korangi Creek and Khobar Creek \\
IR East & Kharo-Chhann and Shah Bandar, located between Ghara-Chan Creek and Sir Creek \\
\hline
\end{tabular}

\section{Materials and Methods}

\subsection{Data Set for Coastline Delineation}

The IDR creek system is under the influence of high tides [26], medium to high energy waves [32], and sea level rise of over $1.1 \mathrm{~mm} / \mathrm{yr}[27,33]$. The coastline delineated from satellite images varies with 
the tidal height when the satellite passes [34] (Figure 2). The National Institute of Oceanography (NIO), Pakistan, monitors the ocean tide height using a fixed tide gauge located at Port Muhammad Bin Qasim $\left(24.7833^{\circ} \mathrm{N}, 67.3500^{\circ} \mathrm{E}\right)$. The tidal status at the time of image acquisition was based on astronomical tidal height predictions from Tides 4 Fishing (https://tides4fishing.com/), which provides expected tidal height values and the times they are likely to occur. The data from the tide gauge show that the tidal height varied approximately between 0.20 to $2.80 \mathrm{~m}$ during the passes of Landsat TM (Thematic Mapper) and OLI (Operational Imager) over the past three decades (Table 2).

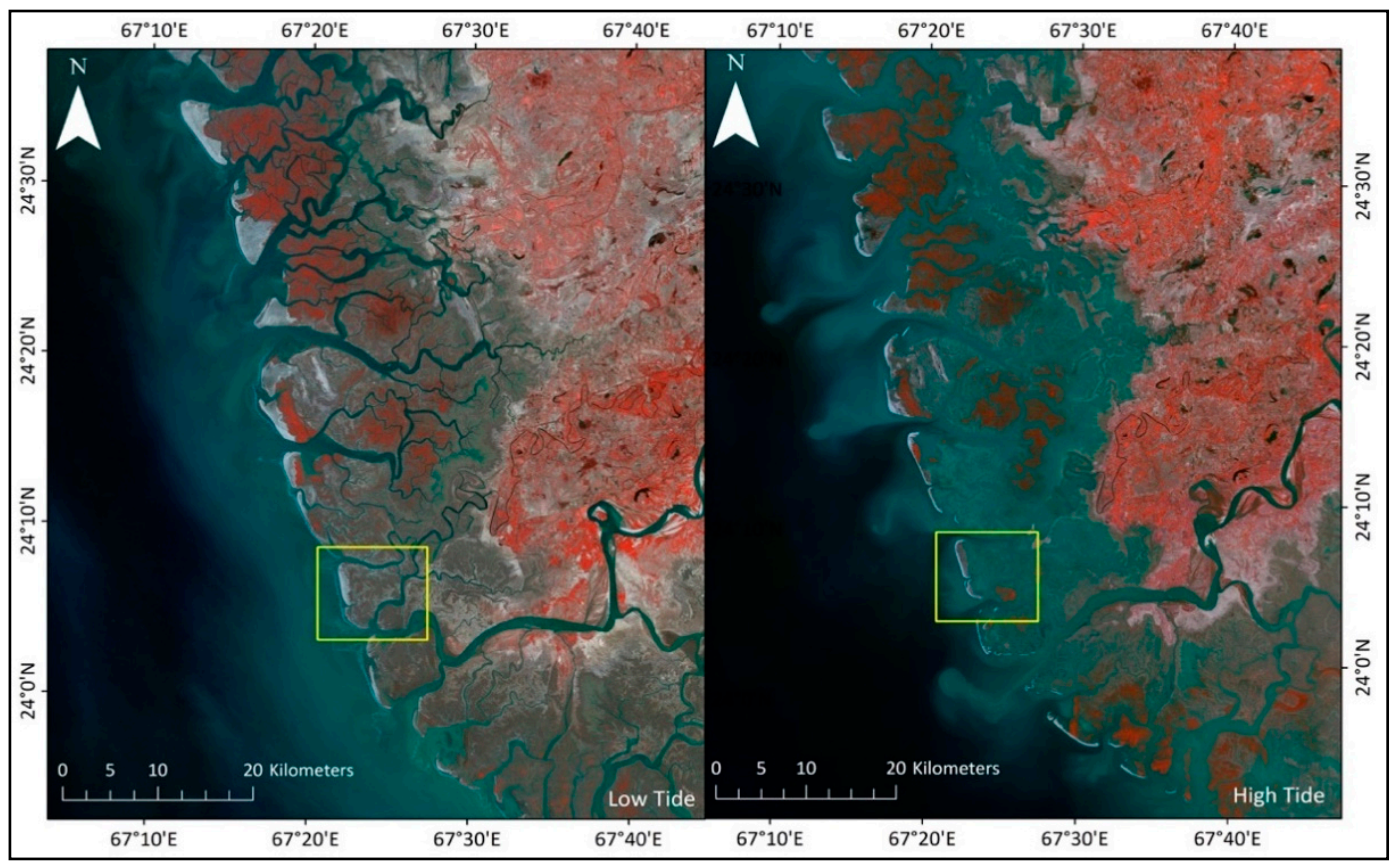

Figure 2. Different tidal flat exposures of IDR at high tide (left) and low tide (right) in Landsat OLI images (band 5,3,2).

We selected only cloud-free and atmospherically corrected 30-m Landsat (TM: Thematic Mapper and OLI: Operational Image Processor) images acquired in non-flooding pre-monsoon season (Dec-April) to evaluate the geomorphological change of the coastline [27,35]. All the Landsat CDR (climate data records) images were pre-processed to L1T level (i.e., after standard terrain correction) with consistent geo-registration and within the prescribed tolerances (i.e., $12 \mathrm{~m}$ root-mean-square error) [11]. Due to the data availability and tidal level constraint $(\leq 2.8 \mathrm{~m})$, only some of the cloud-free images were suitable. The final data set contained 17 images from path 152, row 043. Four of these images were used for coastline delineation and change analysis. The data used, the software for processing the data, and related information are provided in Table 2. 
Table 2. Details of data used in the study.

\begin{tabular}{|c|c|c|c|c|c|c|c|}
\hline \multirow[b]{2}{*}{ Dataset } & \multirow{2}{*}{ Description } & \multirow{2}{*}{$\begin{array}{l}\text { Processing } \\
\text { Level }\end{array}$} & \multicolumn{4}{|c|}{ Spatial and Temporal Resolution } & \multirow[b]{2}{*}{ Source } \\
\hline & & & Pixel Size & $\begin{array}{l}\text { Acquisition } \\
\text { Time (UTC) }\end{array}$ & $\begin{array}{l}\text { Acquisition } \\
\text { Date }\end{array}$ & $\begin{array}{l}\text { Tidal } \\
\text { Height }\end{array}$ & \\
\hline \multirow{4}{*}{$\begin{array}{l}\text { Satellite } \\
\text { Images }\end{array}$} & \multirow{3}{*}{$\mathrm{TM}$} & \multirow{4}{*}{ Level 2} & $30 \mathrm{~m}$ & 05:26:11 & 3 April 1989 & $1.90 \mathrm{~m}$ & \multirow{4}{*}{$\begin{array}{l}\text { US Geological Survey } \\
\text { (https: } \\
\text { //espa.cr.usgs.gov/) }\end{array}$} \\
\hline & & & $30 \mathrm{~m}$ & 05:41:59 & 6 April 1999 & $2.5 \mathrm{~m}$ & \\
\hline & & & $30 \mathrm{~m}$ & 05:44:13 & 10 April 2009 & $0.1 \mathrm{~m}$ & \\
\hline & OLI & & $30 \mathrm{~m}$ & 05:56:49 & 2 March 2018 & $2.80 \mathrm{~m}$ & \\
\hline \multirow{2}{*}{$\begin{array}{l}\text { Ocean } \\
\text { Data }\end{array}$} & Mean Tide Level & - & \multicolumn{4}{|c|}{ 1989-2018 } & $\begin{array}{l}\text { Tides } 4 \text { Fishing (https: } \\
\text { //tides4fishing.com/) }\end{array}$ \\
\hline & $\begin{array}{c}\text { Mean Sea Level } \\
\text { Data }\end{array}$ & - & \multicolumn{4}{|c|}{ 1916-2015 } & $\begin{array}{l}\text { Permanent Service for } \\
\text { Mean Sea Level } \\
\text { (PSMSL) [36] }\end{array}$ \\
\hline Topography & $\begin{array}{c}\text { Shuttle Radar } \\
\text { Topography } \\
\text { Mission (SRTM) }\end{array}$ & - & \multicolumn{4}{|c|}{$30 \mathrm{~m}$} & $\begin{array}{l}\text { Open-Topography } \\
\text { (http://opentopo.sdsc. } \\
\text { edu/datasets) }\end{array}$ \\
\hline
\end{tabular}

\subsection{Data Set for Coastline Delineation}

\subsubsection{Coastline Delineation}

Toure et al. [37] reviewed various approaches used for coastline delineation from remote sensing imagery using various image processing methods. These methods to determine the coastal changes include pixel frequency count, image histogram thresholding [38], edge filter algorithm and tasseled cap transformation [18], and image classification through iterative self-organizing data analysis (ISODATA) [39]. We adopted an automatic coastline delineation method that consists of the following steps [40]: (a) band selection based on spectral profile curve of the images; (b) selection of the optimal index for coastline delineation; and (c) coastline delineation based on histogram threshold. The comprehensive framework is shown in Figure 3.

Prior to coastline delineation, all the satellite images are georeferenced and projected to a common Universal Transverse Mercator (UTM) map system (42N Zone) using ENVI 5.3 (ENvironment for Visualizing Images). ENVI's $X$ and $Y$ coordinates and arbitrary profiles (transects) are used to generate terrain profiles perpendicular to the coastline and analyze the spectral profile curves of the final composite normalized images (i.e., image composite of all spectral bands) to identify the suitable signal bands for coastline delineation. Shortwave infrared Band $5(1.55-1.75 \mu \mathrm{m})$ is well-suited to extract the land-water interface from Landsat TM [41] and OLI images [18], as it shows the highest gradient between the seawater and the land (Figure S1). The modified normalized difference water index (MNDWI) was implemented to the images of 1989, 1999, 2009, and 2018, using the equation:

$$
M N D W I=(\text { Green }-M I R) /(\text { Green }+M I R),
$$

where Green is the green band (band 2 for Landsat TM/ETM+ data and band 3 for Landsat OLI data) and MIR is the middle infrared band (band 5 for Landsat TM/ETM+ data and band 6 for Landsat OLI data). MNDWI is a modification of the normalized difference water index (NDWI) and has been widely used in detecting water surfaces.

The object-based image analysis (OBIA) was finally carried out for automatic delineation of the land-water interface by applying the histogram threshold to the MNDWI images. Suitable thresholds were determined for each index image in a trial-and-error process. A threshold value of -0.5 was found to be stable and repeatable for coastline mapping based on the MNDWI. 


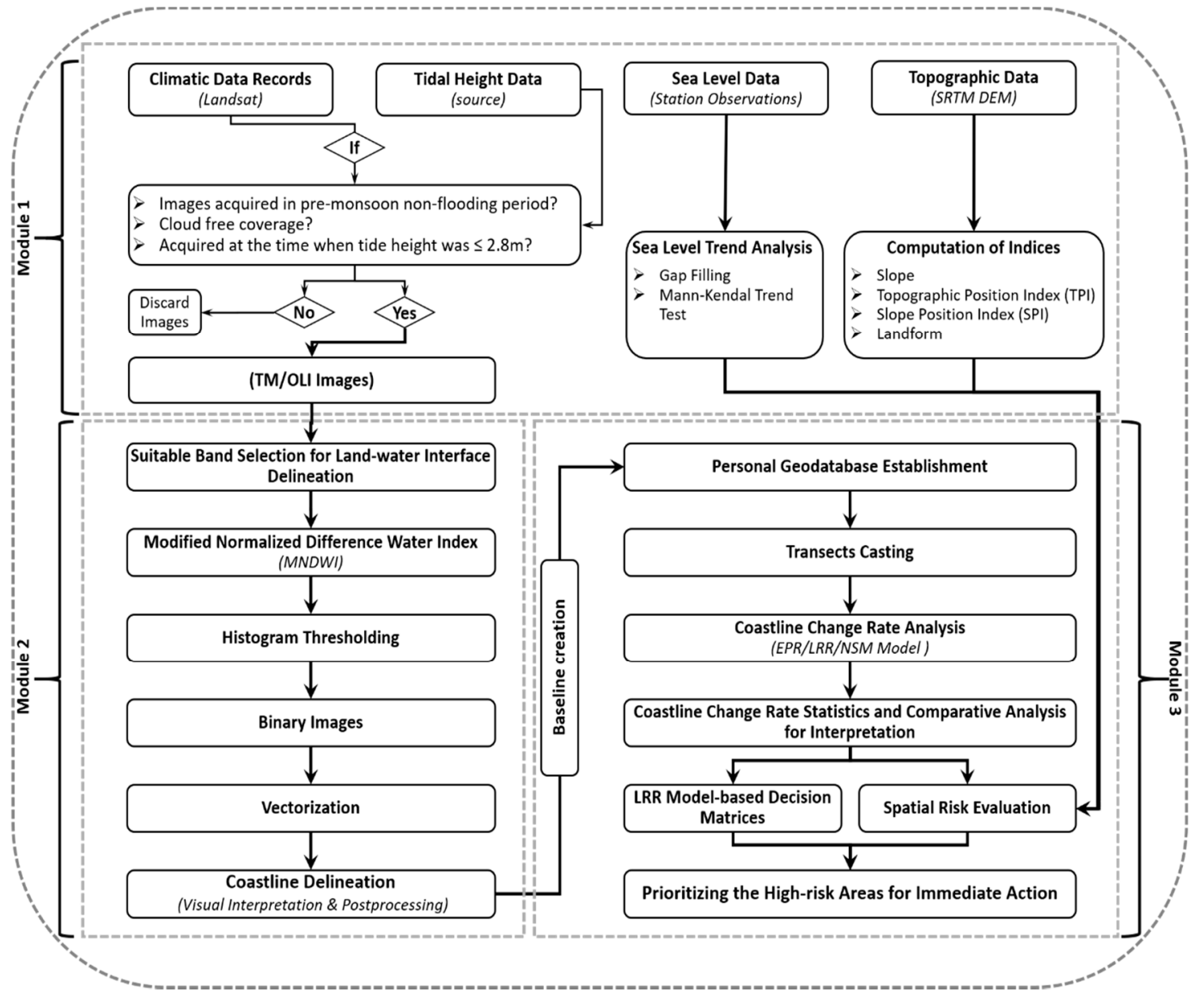

Figure 3. Data processing framework.

Each land-water classified image was compared with their corresponding Landsat image for visual assessment and to ensure the quality of the classification results. The continuous edge representing the coastline was delineated using an edge detection approach based on a morphological filter [40]. The binary data were then converted into vector format for further assessment. All the inland water bodies, such as lakes, that are not adjacent to the Arabian Sea were removed. It was noted that the study area has very dense dendritic networks of creeks extending from $\sim 180 \mathrm{~km}$ along the coast and $32 \mathrm{~km}$ landward. Using prior spatial knowledge, about $2.5 \mathrm{~km}$ inward passage was identified as a coastline.

\subsubsection{Analysis of Coastline Change}

Decadal coastline change was analyzed systematically using the Digital Shoreline Analysis System (DSAS) [18,42] developed by the USGS. The following computation was carried out to compute the change rate: (a) coastline delineation; (b) baseline generation; (c) transects generation; (d) computation of distances between the coastline and the baseline at each transect; and (e) estimation of coastline change rate at each transect. Each coastline computed was assigned five attributes, i.e., date, length, ID, shape, and uncertainty. We selected the 1989 coastline as a benchmark, as 1989 is the start of the data series and the year that the United Nations Environment Programme (UNEP) included Pakistan in the group of countries vulnerable to the impact of rising sea level [29]. Among the three existing methods for baseline demarcation (i.e., creating a baseline from a specific distance of a coastline, using a pre-existing baseline, and buffering method), we adopted the buffering method, as it is considered to be the most reliable and accurate [43].

Following Nandi et al. [43], a buffer of $200 \mathrm{~m}$ was generated around the baseline coastline. Two hundred meters was chosen as the optimal baseline distance after a trial-and-error process. Baseline 
was segmented into onshore and offshore following the coastline as best as possible, and transects were cast using the delineated coastlines and the baseline. A total of 1232 transects were cast along the coastline at intervals of $500 \mathrm{~m}$. The spacing was determined after trying different options, including $200,300,400,500,600$, and $700 \mathrm{~m}$. The spacing of $500 \mathrm{~m}$ was found to be optimal, as it caused less intersection between the transects. Transect length was chosen as the maximum distance between the baseline and the farthest coastline (2000 $\mathrm{m}$ in the study). The transects were numbered from 1 to 1232 , with 1 on the far west and 1232 at the far east of the coastline. Three different statistical models (i.e., end point rate (EPR), linear regression rate (LRR), and least median of squares (LMS)) in the DSAS program were used to compute the rate of coastline change. The EPR method calculates the coastline change between two coastlines separated by a certain time period (years), using:

$$
E P R=\frac{d 1-d 2}{t 1-t 2}
$$

where $d 1$ and $d 2$ are the distances separating the coastlines and the baseline, and $t 1$ and $t 2$ are the dates when the coastlines are observed. EPR was calculated based on three time periods, i.e., 1989-1999, 1999-2009, 2009-2018, and for 1989-2018. The confidence of EPR (ECI) is calculated as:

$$
\mathrm{ECI}=\frac{\sqrt{\operatorname{Unc}(A)^{2}+\operatorname{Unc}(B)^{2}}}{\text { Date } A-\text { Date } B},
$$

where $U_{n c}(A)$ and $U_{n c}(B)$ are the uncertainty values for coastlines $A$ and $B$, respectively, Date $A$ and Date $B$ are the dates of coastlines $A$ and $B$, respectively.

The LRR method computes the coastline change by linear least-squares regression of multiple coastline positions (i.e., 1989, 1999, 2009, and 2018) for each transect:

$$
d=b+m X
$$

where $d$ represents the distance from the baseline, $X$ is the time interval, $m$ is the slope of the fitted line, and $b$ is the $y$-intercept. The slope of the fitted line $(m)$ represents the rate of coastline change. The R-squared $\left(R^{2}\right)$ value of the linear regression is calculated for each transect:

$$
R^{2}=1-\sqrt{\frac{\sum_{i=1}^{n}(d-d p)^{2}}{\sum_{i=1}^{n}(d-\bar{d})^{2}}},
$$

where $d$ is the known distance of an observed coastline from the baseline, $d p$ is the predicted value of $d$ based on the regression equation, $\bar{d}$ is the mean position of the coastline, and $n$ is the number of observed coastlines. In this study, $R^{2}>0.87$ is used as the limit of certainty, following [18]. The uncertainty of the calculated rate, also known as the standard error of the slope of the regression line, is reported as confidence interval of the line of regression (LCI). The LCI is considered at confidence interval of $95 \%(p=0.05)$, i.e., LCI95.

In the LRR method, the mean offset of the sample is used to determine the best-fit equation for the regression line. Whereas, the LMS method uses the median value of the squared residuals instead of the mean offset in order to determine the equation for the slope line.

The observed coastlines were superimposed on the corresponding Landsat images to check their accuracy. The coastline for the year 2018 was also predicted with the LRR model based on coastlines of the previous years $(1989,1999$, and 2009). Correlation between the predicted and the actual coastlines demonstrates the accuracy of the observed coastline and the regression model. 


\subsubsection{Classification of Erosion}

We adopted a classification scheme from Gornitz et al. [44] and divided the coastline change rate into five classes (i.e., $>2.0,1.1-2.0,-1.0$ to $1.0,-1.1$ to -2.0 , and $<-2.0 \mathrm{~m} / \mathrm{yr}$ ), where the positive values indicate accretion and the negative values indicate erosion. An intensity curve was plotted based on the LRR for each subzone. A linear regression statistics-based decision matrix was also devised to assess the severity of erosion/accretion in each zone and subzone $[17,45]$.

\subsubsection{Influencing Factors for Coastline Change}

The terrain slope along each transect is measured as a ratio of elevation difference between upslope point A and downslope point B to the distance. The slope, calculated based on SRTM (Shuttle Radar Topography Mission) 30-m DEM in terms of percentage rise, was plotted and analyzed using the spatial analyst tool in ArcGIS. A topographic position tool (TPI) developed by Jenness [46] was further used to analyze the spatial variation in the nearshore topography. Nearshore topography and the location of the coastlines in 1989, 1999, 2009, and 2018 were compared to study the patterns of erosion/accretion in relation to the topography.

Statistical analysis of the mean sea level data for the period of 1916-2015, obtained from the Permanent Service for Mean Sea Level (PSMSL) archive, was carried out to evaluate the trend of SLR. A non-parametric Mann-Kendall test for statistically significant increasing/decreasing trend $[47,48]$ and Sen's slope method to estimate the magnitude of the trend of sea level rise were applied [49,50]. The information was coupled with coastal erosion to discuss the possible impacts of SLR on coastal erosion. It is noted that the data from PSMSL considers both the climatic SLR and geological SLR. Hence, the results should be interpreted as such if any correlation between erosion and PSMSL data exists.

\section{Results and Discussion}

\subsection{Coastline Delineation}

The image-based coastlines of the Sindh over 1989-2018 are shown in Figure 4. The results show that almost the entire coast experienced either accretion or erosion, except for the Karachi-West, which has been converted into the artificial hard coastline. The IR West and IR East coastal regions experienced erosion up to 14.17 and $19.76 \mathrm{~m} / \mathrm{yr}$, respectively. This erosion rate is greater than that of the Karachi coastline $(0.85 \mathrm{~m} / \mathrm{yr})$. The assessment of image-based delineated coastline through geometric evaluation remains the focus of scientific discussion. Image-based coastline uncertainty is subjective and probably more difficult, especially when no reference datasets are available for such a large area in undeveloped deltaic regions. In order to evaluate the coastline accuracy, initially we searched for high-resolution data such as aerial orthophotos or freely available high-resolution satellite images such as Sentinel-2 that coincide with dates of Landsat images used. Little information is found that matches the close date and no information for the same date. Therefore, results of this study have been verified by authors through personal communications with the local authorities and residents wherever possible. 


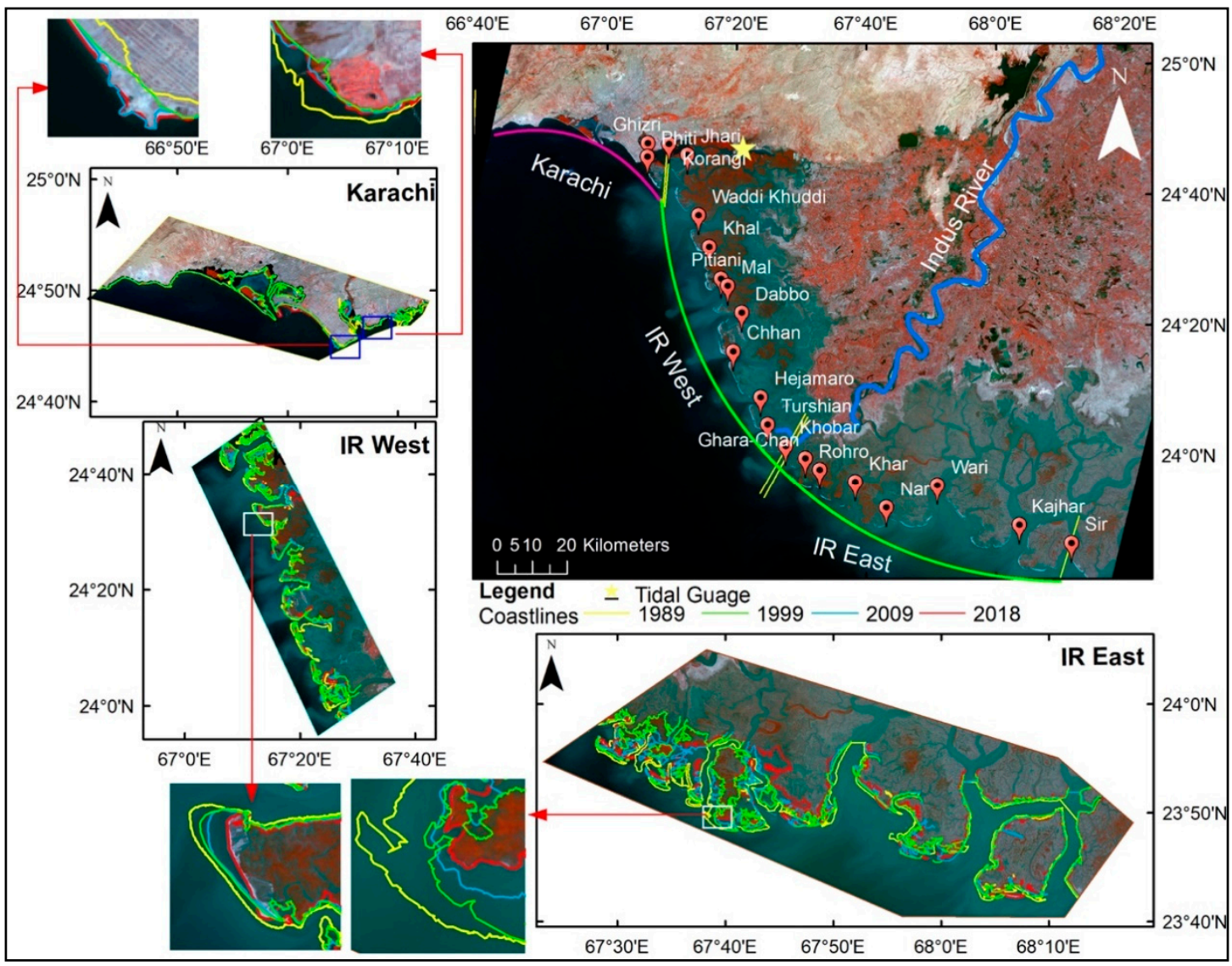

Figure 4. Coastlines retrieved from Landsat Thematic Mapper (TM) and Operational Land Imager (OLI) images acquired between 1989 and 2018, superimposed on the OLI image acquired on 2 March

2018. The results show the coastline changes over a 30-year period.

\subsection{Analysis of the Rate of Coastline Change}

The obtained $R^{2}$ value between EPR and LRR is very high $\left(R^{2}=0.94\right.$, Figure S1). Since the affinity between EPR-LRR is high, compared to that of EPR-LMS $\left(R^{2}=0.80\right)$ and LMS-LRR $\left(R^{2}=0.91\right)$, and because LRR is the most widely used method for coastline change rate estimation, we use the results from the LRR model to further analyze the coastline changes. The LRR method is considered the most reliable estimator of the rate of change in coastline position [51] and forecaster of trends for the future, as it minimizes the potential random error and short-term variability [52,53].

A validation step was carried out to assess the quality of the LRR-based statistical results through correlation analysis between the remotely sensed coastline and the model-predicted coastline for the year 2018. The correlation between the model-predicted and the actual coastlines was found to be $90 \%$. Overlapped areas along the Sindh coastline between predicted and remotely sensed coastlines for the year 2018 can be found in Figure 5. Both the statistical and graphical assessments confirmed that the LRR model-predicted coastline values were in close agreement with the remotely sensed coastline values for all the zones. Therefore, results are acceptable for further analysis. 


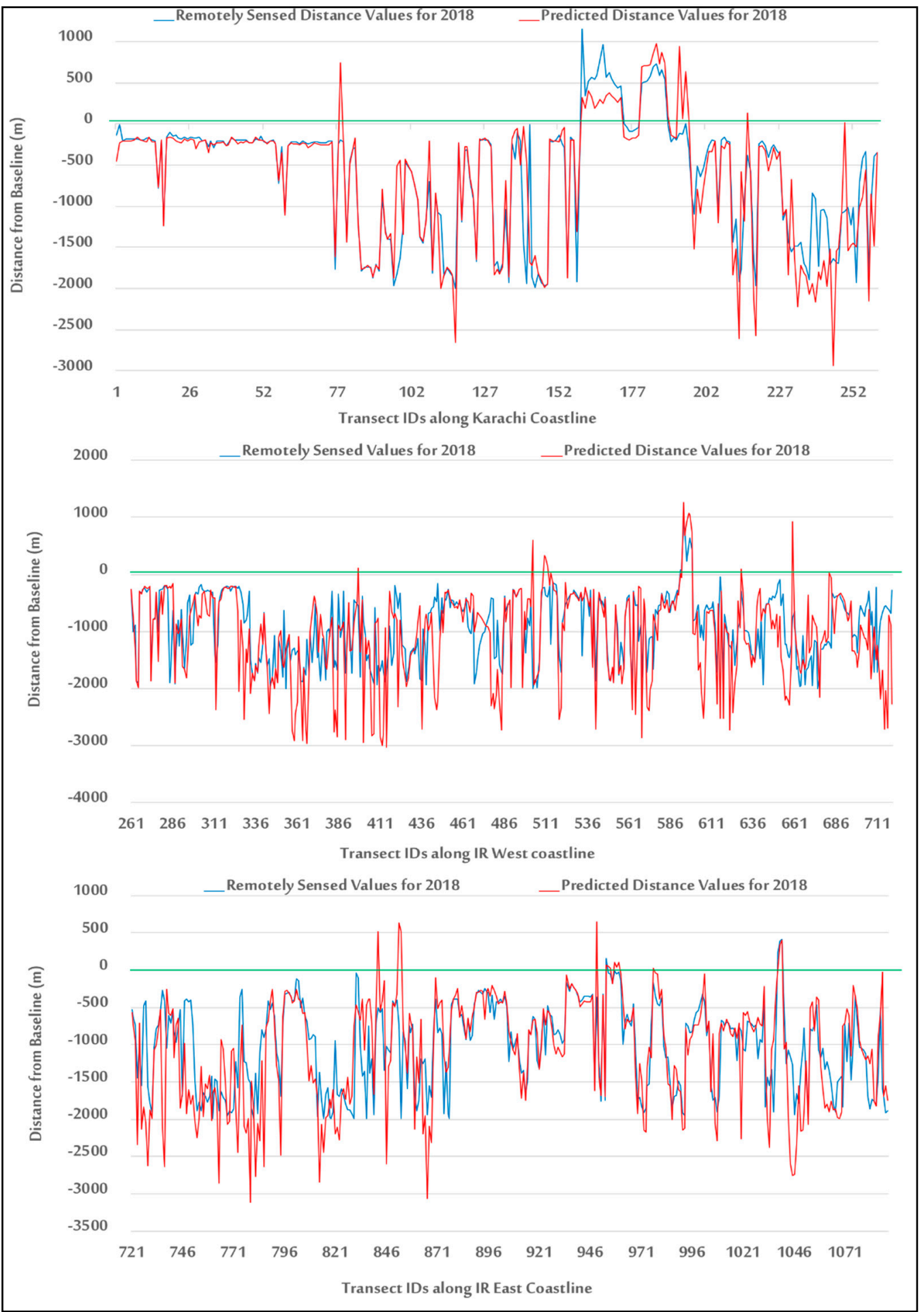

Figure 5. Graphical representation of the overlapped areas along the Sindh coastline between predicted and remotely sensed coastlines. The green line represents the zero-reference line (i.e., a baseline from which the distance of each point on the coastline is measured).

\subsection{Coastline Change Rate Statistics during the Last Three Decades (1989-2018)}

All the zones exhibit both accretion and erosion along the coastline during the study period. The demarcations of these two classes (erosion/accretion) from the LRR model-based statistical output for Karachi, IR West, and IR East zones are presented in Figure 6. Detailed information on the minimum, 
maximum, and average in each class (erosion/accretion) for each zone and subzone in this study is given in Table 1.

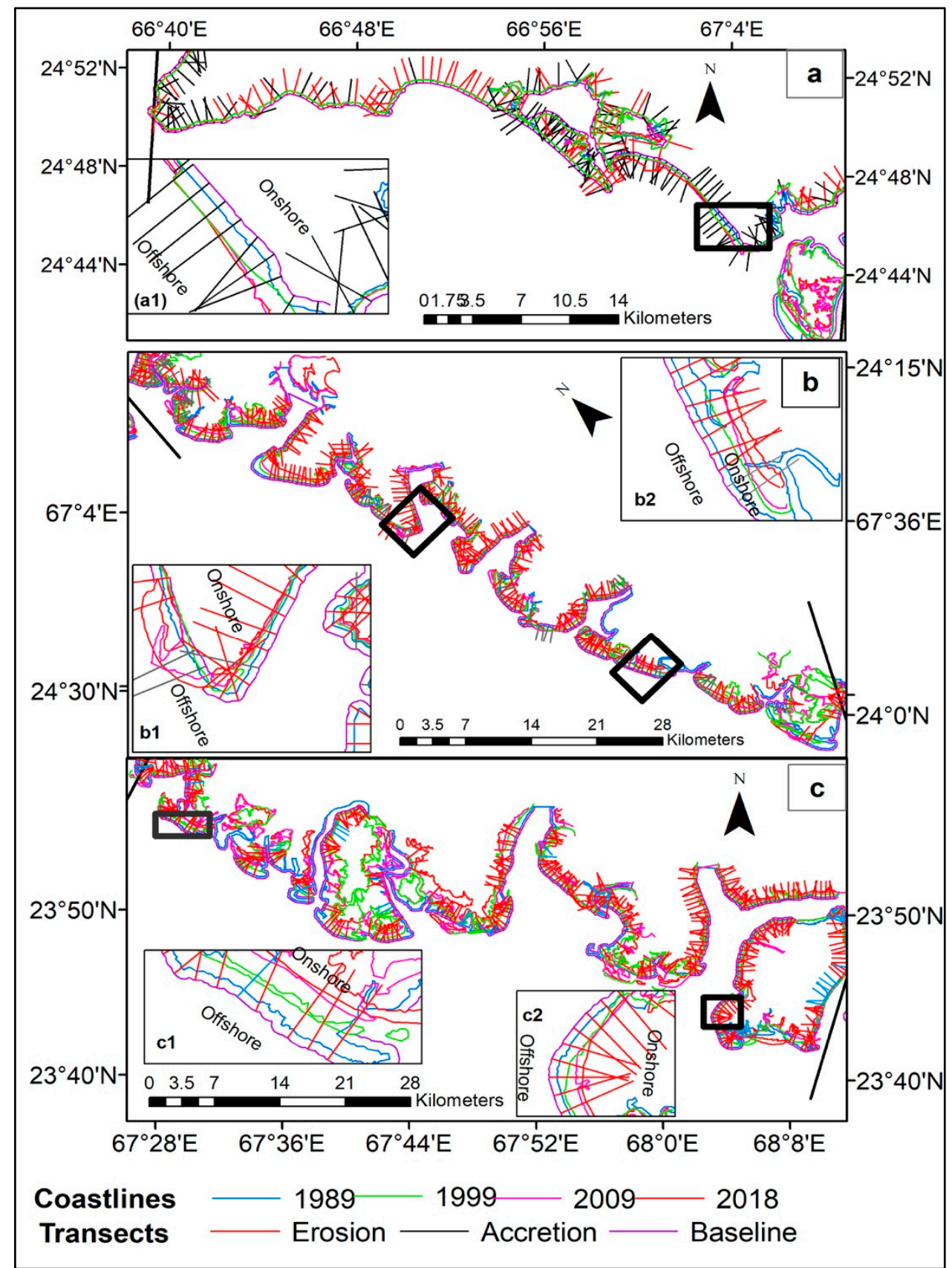

Figure 6. Spatial qualitative analysis of erosion/accretion at each transect using the linear regression rate (LRR) model based on Digital Shoreline Analysis System (DSAS) and the delineated coastlines in the study period for (a) Karachi, (b) IR West, and (c) IR East zones.

The Karachi zone falls in the low erosion category $(-0.85 \pm 0.45 \mathrm{~m} / \mathrm{yr})$, which is mainly contributed to by the erosion of the outlying islands (Table 3). Results show that the western parts of the Karachi coastline have been relatively less unstable as compared to other subzones during the last three decades. The IR West zone and the IR East zone (covering IDR) were highly eroded during 1989-2018 with mean erosion levels of $-14.17 \pm 0.45$ and $-19.96 \pm 0.55 \mathrm{~m} / \mathrm{yr}$, respectively. The highest average erosion rate among all three zones was experienced by the subzone Kharo-Chhann, located in IR East (-27.46 m/yr), 
during the past three decades. The highest accretion rate $(12.14 \mathrm{~m} / \mathrm{yr})$ is observed at the transects along the subzone Karachi South coastline, which is a potential result of coastal reclamation. While erosion is prevalent in the IDR, the change rate assessment results show that rates of the landward erosion experienced an increasing trend from the west to the east along the Pakistan coastline (Figure 7). The distance (in meters) values from the baseline at each transect are analyzed for the interdecadal variations during 1989-1999, 1999-2009, and 2009-2018. Large segments of the coastline are found to be receding landward from 1989 to 2018 . This statement is supported by a linear increase in average change in distance from baseline $\left(R^{2}=0.78\right.$, Figure 8$)$.

Table 3. Global LRR statistics of all the study area coastline change rate (m/yr) during (1989-2018) period (details on the end point rate (EPR) and least median of squares (LMS) statistics can be found in Table S1).

\begin{tabular}{lcccccccc}
\hline Zone & \multicolumn{3}{c}{ Karachi Zone } & \multicolumn{3}{c}{ IR West Zone } & \multicolumn{3}{c}{ IR East Zone } \\
\hline Subzone & $\begin{array}{c}\text { Karachi } \\
\text { West }\end{array}$ & $\begin{array}{c}\text { Karachi } \\
\text { South }\end{array}$ & $\begin{array}{c}\text { Karachi } \\
\text { East }\end{array}$ & $\begin{array}{c}\text { Mirpur } \\
\text { Sakro }\end{array}$ & $\begin{array}{c}\text { Keti- } \\
\text { Bandar }\end{array}$ & Ghorabari & $\begin{array}{c}\text { Kharo- } \\
\text { Chhann }\end{array}$ & $\begin{array}{c}\text { Shah- } \\
\text { Bandar }\end{array}$ \\
\hline No. of transects & 128 & 69 & 13 & 385 & 122 & 137 & 106 & 272 \\
Mean accretion rate (+) & 4.01 & 12.14 & 9.37 & 11.49 & 7.87 & 11.53 & 10.72 & 11.88 \\
Mean erosion rate (-) & -4.17 & -6.09 & -13.95 & -19.98 & -20.04 & -19.57 & -27.46 & -23.37 \\
Min accretion rate (+) & 0.00 & 0.28 & 0.00 & 0.02 & 0.12 & 0.12 & 0.46 & 0.01 \\
Max erosion rate (-) & -74.59 & -48.86 & -57.22 & -72.66 & -52.35 & -65.46 & -62.36 & -64.85 \\
Max accretion rate (+) & 48.26 & 53.61 & 51.09 & 62.04 & 43.64 & 51.09 & 32.17 & 48.76 \\
Min erosion rate (-) & -0.02 & -0.05 & -0.20 & -0.11 & -0.25 & -0.25 & -1.30 & -0.41 \\
\hline Zonal average & \multicolumn{3}{c}{$-0.85 \pm 0.45$} \\
\hline Category & \multicolumn{3}{c}{ Low Erosion } & \multicolumn{7}{c}{ Severe Erosion } & $-14.17 \pm 0.55$ & Severe Erosion \\
\hline
\end{tabular}

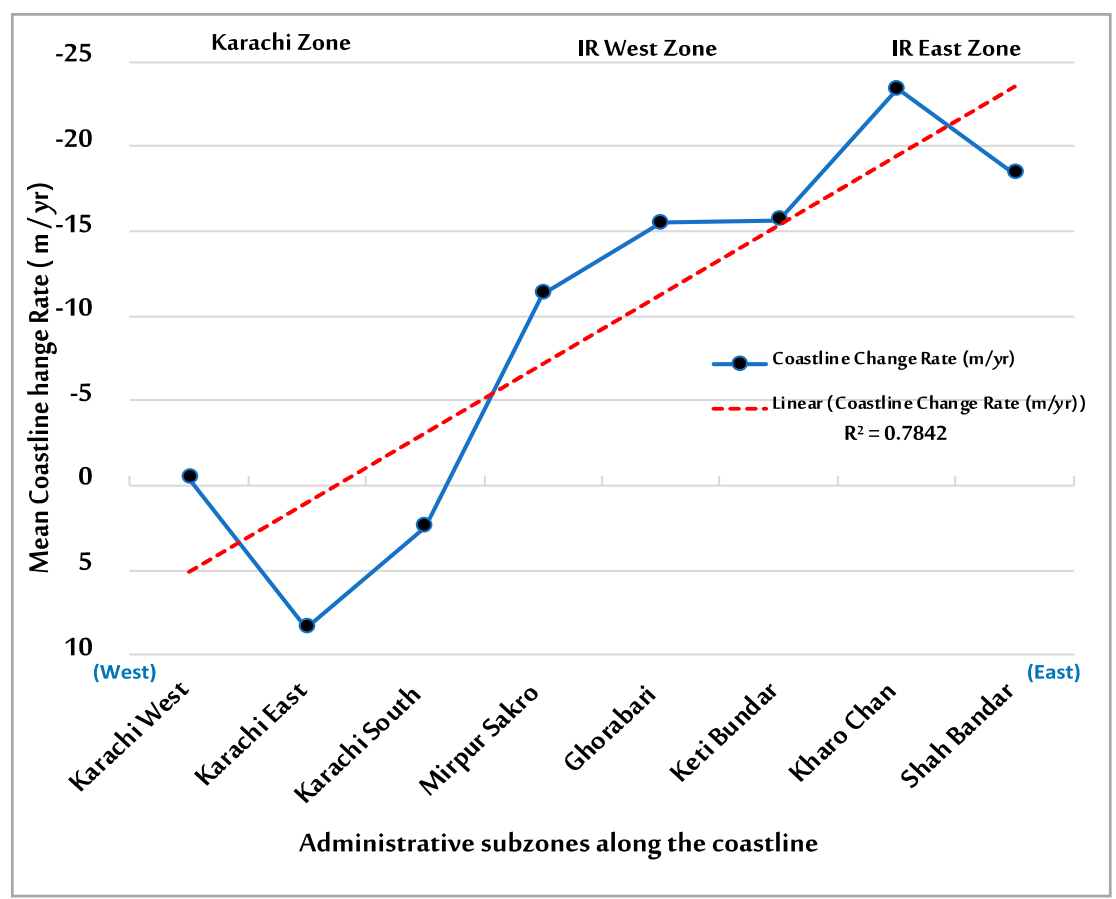

Figure 7. Longitudinal profile of the mean coastline change rate along the study area coastline. Values $>0$ shows accretion and values $<0$ represent erosion. While erosion is prevalent in the IDR, the linear spatial trend of the mean coastline change per year indicates that erosion is increasing eastward. 


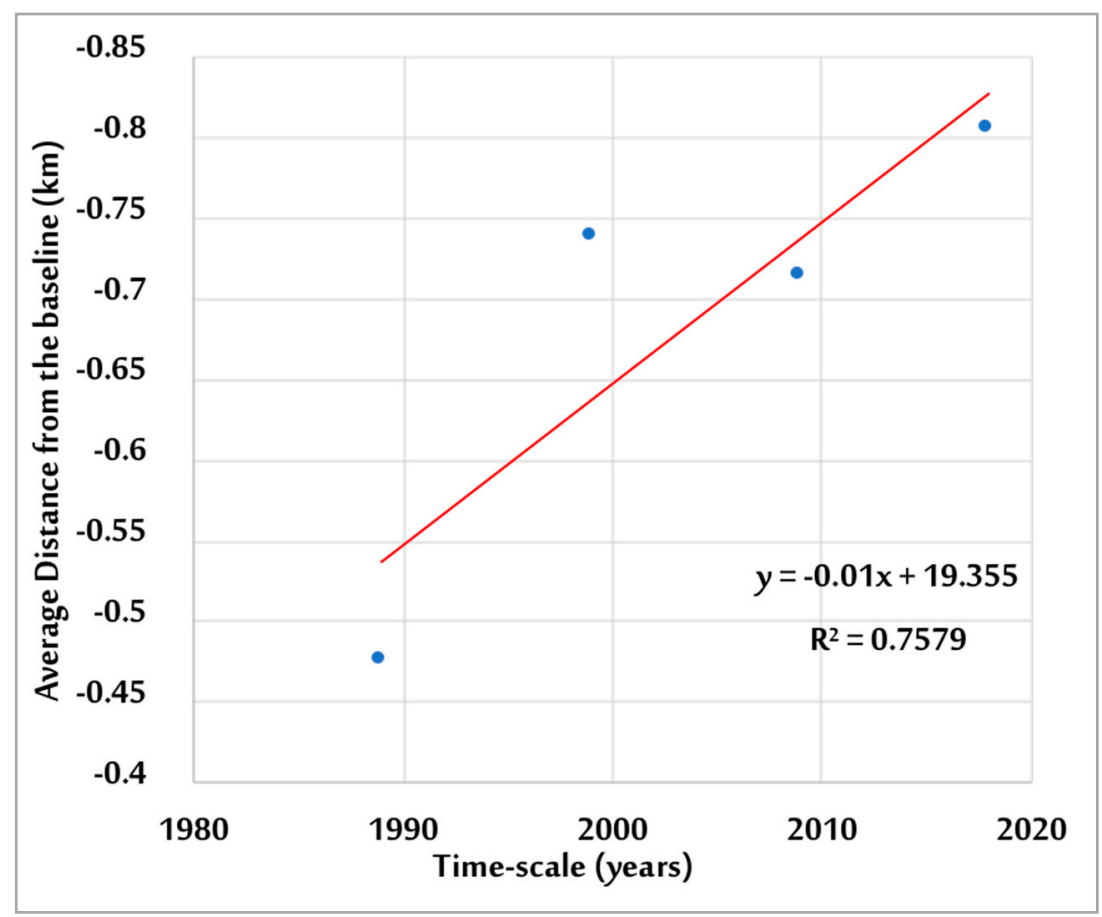

Figure 8. Coastline mean interdecadal change during the 1989-2018 period. The trend (red-colored) indicates a linear increase in the erosion along the coastline.

\subsection{Zone-Wise Coastline Change Rate by LRR Model}

\subsubsection{Karachi Coastline}

Karachi zone is the most developed segment along the Sindh coastline. The prominent features of the Karachi coastline are raised beaches, shallow lagoons, marine terraces, sea cliffs, and sand dunes. A closer inspection of the coastline change statistics for Karachi zone shows that the coastline oscillates between erosion and accretion (Figure 9). The intensity plot shows that the NW-SE oriented Karachi coastline is largely disparate to the subzone Karachi South, as compared to other two subzones (Karachi West and Karachi East). Very high accretion rate (up to $8.34 \mathrm{~m} / \mathrm{yr}$ ) is observed at the south of Korangi Creek entrance and the southern part of Karachi coastline, which forms the coastal segment of subzone Karachi South (Figure 9). These obvious changes in land accretion at the subzone Karachi South are evident in Figure 10 and appeared prominently in the corresponding Landsat TM and OLI images in different years. Accretion measured at the Karachi South subzone is artificial because a large part of the area has been reclaimed from Arabian Sea for coastal infrastructure development [54]. Luijendijk et al. [55] also found this area near Karachi south accreting at very high rate during the 1984-2016 period. A comparison of the satellite images before and during the study period (Figure 10) compliments the results for coastline assessment in this sector (Karachi South). Therefore, we emphasize that the coastal development and construction projects should be designed with great care, as studies confirm that the land in this subzone is susceptible to liquefaction in case of any major earthquake events. 


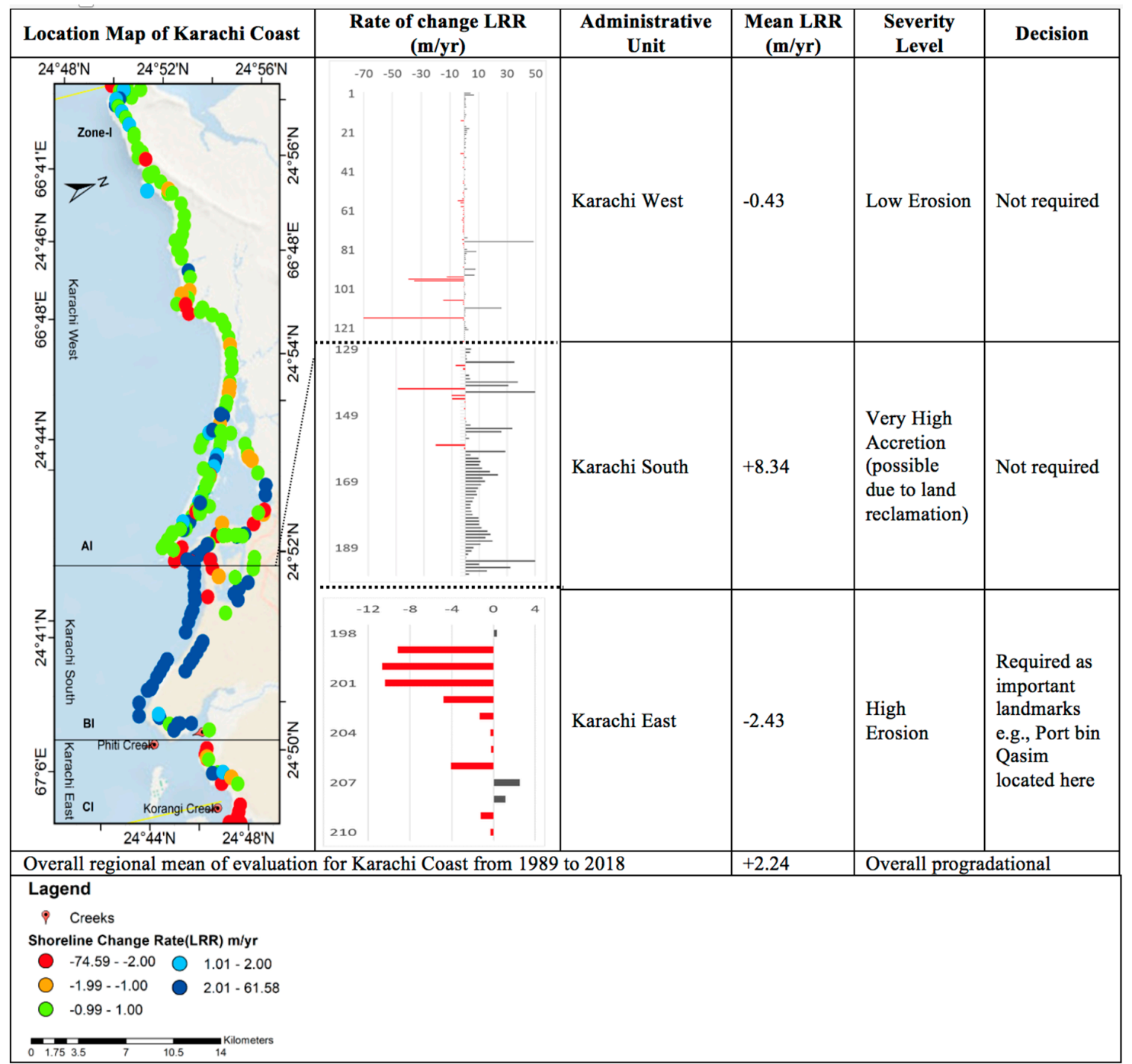

Figure 9. Coastline assessment for Karachi coastline based on linear regression rate (LRR) statistical method over the period 1989-2018. The spatial location of the zone is presented in the first column. The second column represents plot of rate of accretion/erosion against each subzone labeled as "sector". The left axis on the plot shows the transect number increasing from west to east, and the top axis represents the rate of the accretion/erosion in $\mathrm{mm} / \mathrm{yr}$. Further, each subzone is classified into different levels based on the severity of erosion in that sector. Given the severity level, it is analyzed whether some action is required to tackle the erosion problem or not.

Subzone Karachi East (adjacent to IR West zone) is experiencing high erosion (up to $-2.43 \mathrm{~m} / \mathrm{yr}$ ). This area hosts the country's deep-water seaports, Port Bin Qasim (located towards Korangi Creek) and Port Karachi (towards Khizri Creek). Port Karachi is located more inward, whereas Port Bin Qasim is situated on the coastline along the Arabian Sea in subzone Karachi South Widening and deepening of the navigational channel to facilitate the port jetties for the passage of the cargo ships through the Phitti Creek to the seaport Muhammad Bin Qasim has resulted in the coastal erosion in this area. In 1970, when this port started functioning, the presence of barrier islands (Bundal and Buddo Islands) next to the port acted as first line of defense against coastal hazards such as storms and coastal flooding. The high erosion rate in Karachi East subzone is an indication that these natural barriers against the erosional effects of Arabian Sea water are compromised and adversely affected. However, further evaluation in this regard is needed. 

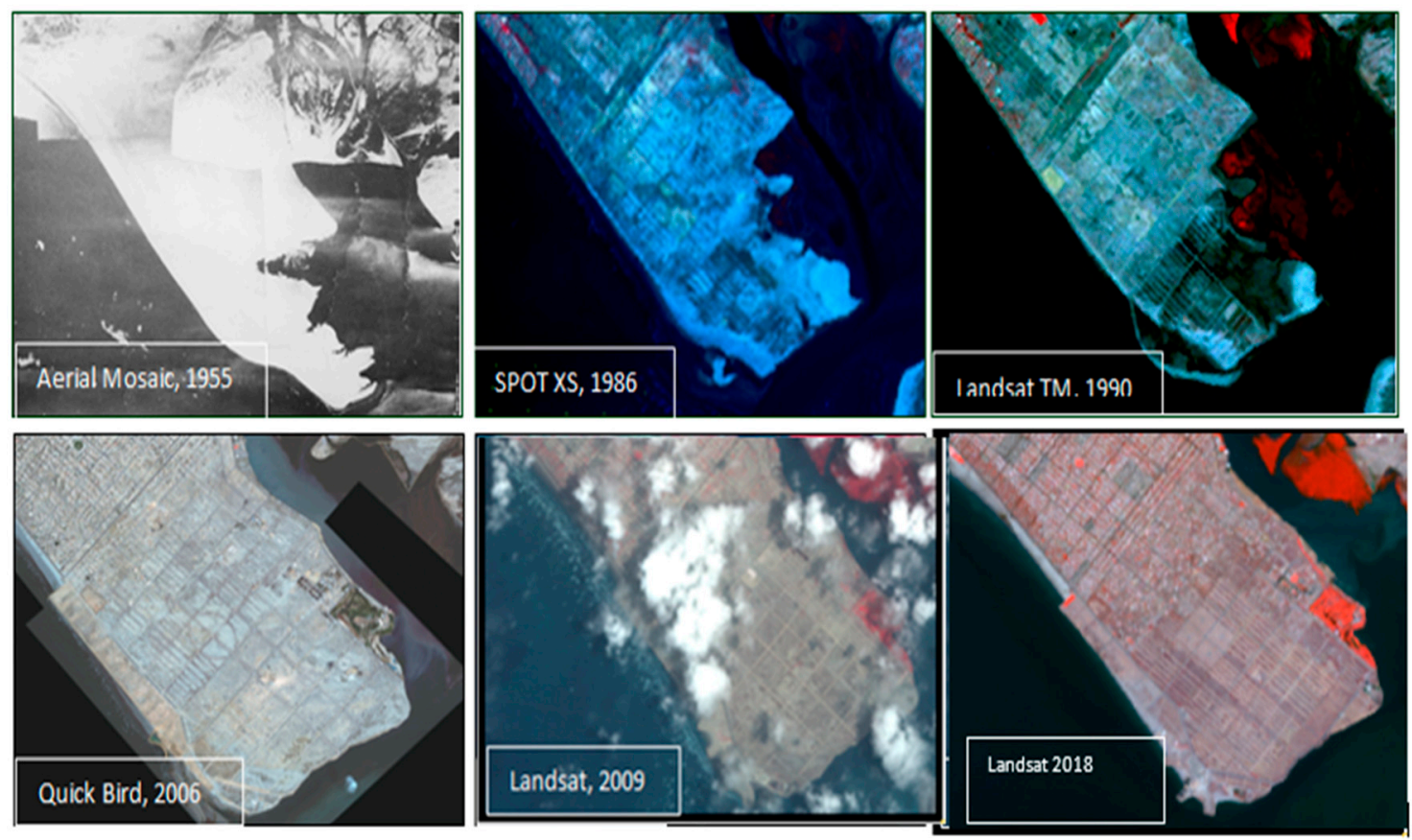

Figure 10. Expansion of Defence Phase VII and Clifton Area over reclaimed land during 1955-2018 (modified from [56]).

\subsubsection{IR West Zone}

Based on the intensity of the advance/retreat curve plot (Figure 11), it is observed that the IR West zone exhibits a very high rate of erosion towards inland with average LRR-based erosion $(14.174 \pm 0.55 \mathrm{~m} / \mathrm{yr})$ increasing from west to east along the IDR coastal stretch. This trend is observed to be correlated with the flat topography. The IR West zone is an embayed coast of tidal mudflats, lagoons, barriers islands, mangrove canopy, and various major creeks. The sector between Waddi/Khuddi and Dabbo creeks in the Mirpur-Sakro subzone is found to be highly erosional and receding at a rate reaching up to $70 \mathrm{~m} / \mathrm{yr}$ during the last three decades. This result also agrees with earlier observations from Giosan et al. [24] and Hashmi and Ahmad [57], who showed that this sector is eroding at very high and similar rates during the post-damming period, mainly due to a reduction in the sediment influx to the Indus River and SWI. Towards the farther east, the coastal sector between Dabbo and Chhan creeks covering the Ghorabari administrative unit also seems to be receding at an average rate of $15 \mathrm{~m} / \mathrm{yr}$, significantly less compared to the subzone Mirpur Sakro However, the maximum erosion rate in Ghorabari coastline segment is found to be increased (up to $50 \mathrm{~m} / \mathrm{yr}$ in most parts).

The coastline segment from Chhan to Hejamaro creeks in subzone Keti-Bandar shows a similar pattern. The results show an interesting and mixed behavior of accretion and erosion at the mouths of Chhan, Hejambaro, and Turshian creeks. The western (left) sides of these creeks are found to be accreting, whereas the eastern and northeastern sides are receding. The coastline sector in front of the two active river mouths between Turshian and Khobar creeks (Keti-Bandar subzone) is found to be encroached by the seawater at a rate reaching up to $50 \mathrm{~m} / \mathrm{yr}$, consistent with the findings of [24], mainly due to the reduced sediment discharge and freshwater inflow. The SW monsoon winds further intensify the land loss processes particularly in the deltaic creeks in this zone. High tidal volume inundates the creek banks and erodes the adjoining coastal lands, which consequently increases the cross-sectional area of the seaward entrance of creeks. The erosion of creek banks destroys woody vegetation (mangroves), particularly near the open coastlines where tidal action is strong (Figure 12). The meandering of small creeks and channels due to increased SWI cut-off from regular floodwater and additional sediment deposits are also some of the causes of natural degradation of mangroves [58,59]. Mangroves are known to protect the coastline from erosion by stabilizing the sediments through their 
prop root systems and dissipating the storm's energy, thus reducing vulnerability to the climate-induced hazard and increasing coastal resilience.

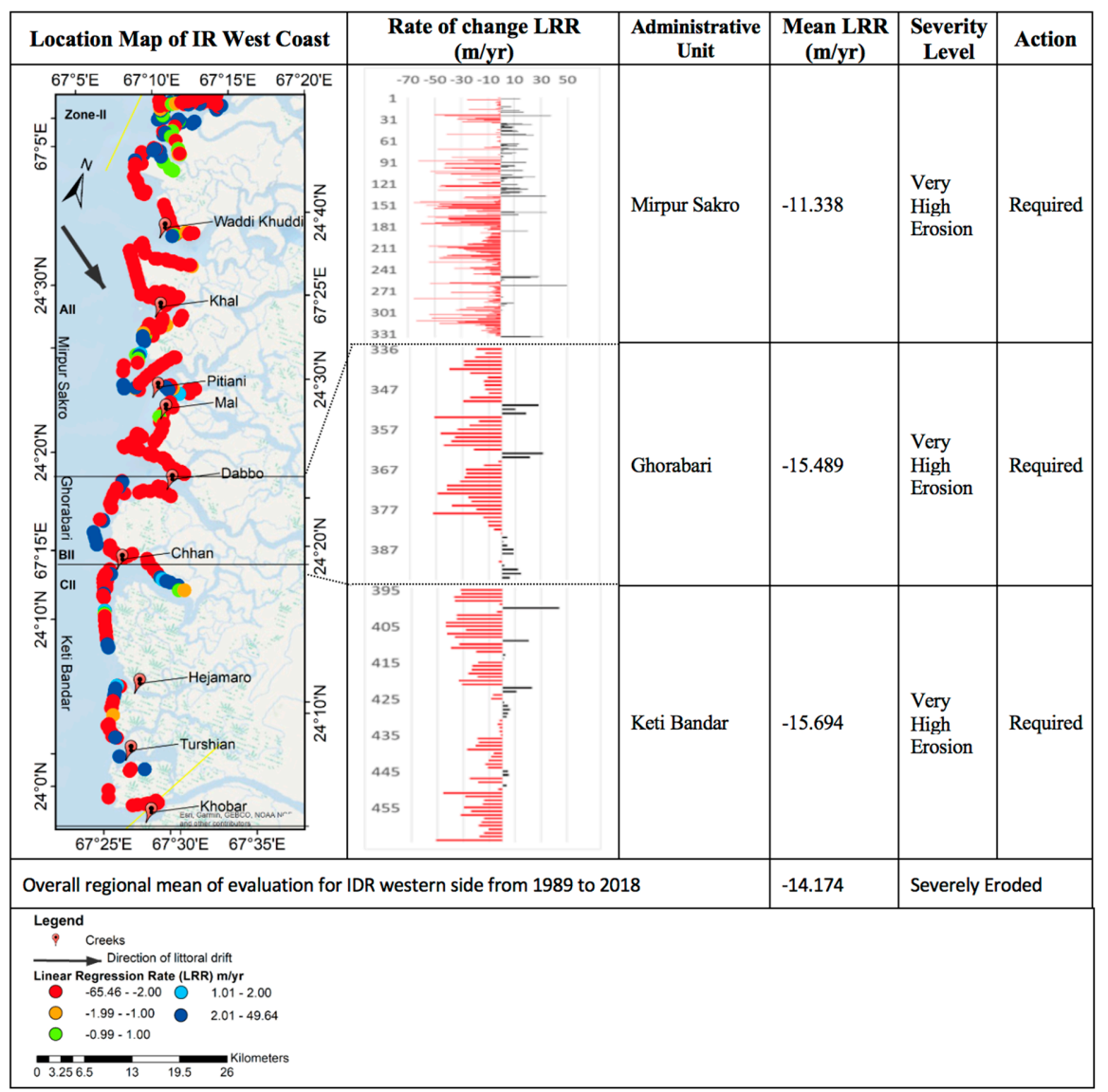

Figure 11. Coastline assessment for IR West zone based on linear regression rate (LRR) statistical method over the period 1989-2018. The description of each column is same as Figure 9.

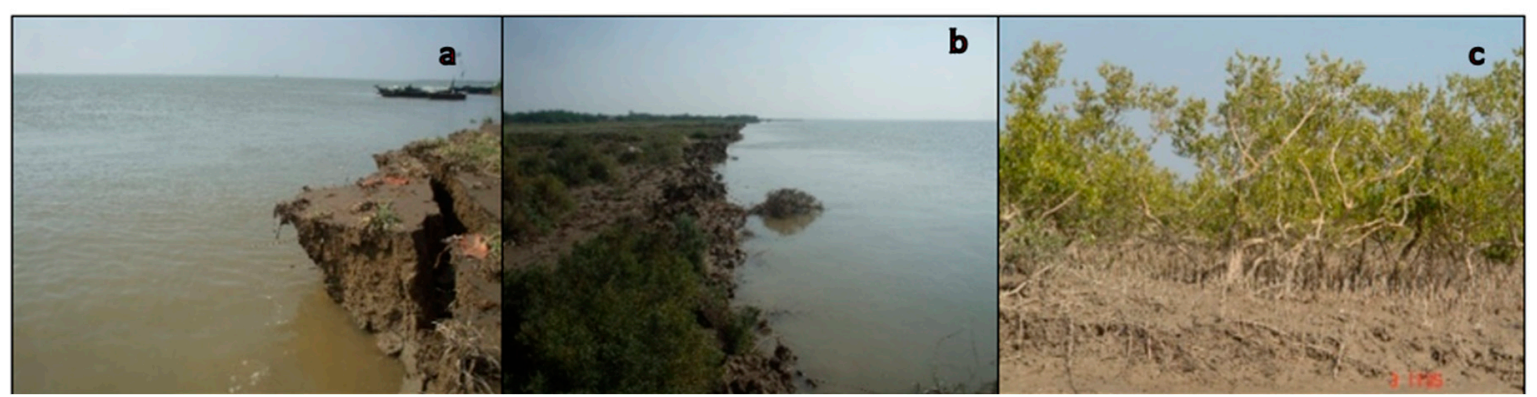

Figure 12. Land erosion and seawater intrusion into coastal vegetation along Sindh coast in Zones II and III. Seawater engulfing the land from a creek bank is visible in (a). Erosion-driven dislodged vegetation can be seen in $(\mathbf{b}, \mathbf{c})$.

\subsubsection{IR East Zone}

Erosive actions are found to be more pronounced in the eastern (right) side of the IDR (i.e., $19.96 \pm 0.65 \mathrm{~m} / \mathrm{yr}$ ) as compared to the IR West zone, and the coastline is receding landward (curve plot, Figure 13). This result is in line with the findings of Waqas et al. [27]. Overall, mean erosion is found to be decreasing away from the Indus River outfall location at Khobar Creek towards Sir Creek in the direction of the littoral drift (long-shore sediment transport) from West to East, as shown in Figure 13. Deltaic soils in this zone are mostly marshy and mudflats and can easily be eroded by waves and other 
oceanic forces of the Arabian Sea. As a result, transects in subzone Kharo-Chhann near the IR outfall have been eroded during the last three decades at an average rate reaching up to $23.42 \mathrm{~m} / \mathrm{yr}$ - the highest among all the subzones. Coastline recession assessment in this zone is consistent with $23 \mathrm{~m} / \mathrm{yr}$ erosion rate estimated by the WWF-Pakistan [60] between 1952 and 2006. The rate of sediment influx and the ground displacements significantly affects the position of the coastline, particularly in the subsiding basins [61]. In the case of IDR and the areas in its vicinity, all the aforementioned factors have varied together greatly with respect to the relative SLR causing larger coastline regression and transgression $[24,26,27,30,62]$.

A gentler topographic profile is observed along the entire IDR coastline (i.e., $0 \%-1.1 \%$ slope for Zone II, and $0 \%-0.3 \%$ slope for Zone III). For complete longitudinal profile, see Figure S3. The results indicate that the IDR is a low-lying coastal area. Based on the analysis of predefined categories of the slope position index (SPI), it is observed that most of the inland areas are at the same level as the Arabian Sea, hence, potentially letting the seawater intrude the surface water resources and salinize groundwater aquifer in this low-lying deltaic region. Slope percentage is below 1.1\% for almost the entire IDR, hence, making the study region vulnerable to impacts of SLR, land erosion, and coastal flooding. Without appropriate measures, rising sea level, inundation/flooding, erosion, and SWI are likely to affect coastal productivity and economic activities in the study region.

The areas at the east of Wari Creek mouth to Sir Creek in subzone Shah-Bandar have experienced erosion at the rate of $18.41 \mathrm{~m} / \mathrm{yr}$ on average. The overall erosion rate of this deltaic coast in this subzone from 1989 to 2018 is less than the average rate reported by Giosan et al. [24] for the same segment during 1978-2000. This might be due to the accumulation of the sediments on this segment due to the along-shore wave dispersal system, which transports the sediments from Indus River outfall and mouth towards the east up to Sir Creek and Rann of Kutch [63]. For this reason, average erosion rate in Shah Bandar taluka is found to be smaller than the Kharo-Chhann. Using the transect-based coastline change rate analysis method, a creek-wise status of the coastal erosion hazard was carried out. Details on minimum, maximum, and average rate of coastline change (m/yr) are given in Table 4 . Transects on the left and right banks of the Waddi, Khal, Pitiani, Dabbo, Chhann, Khobar, Ghara-Chhann, Kajhar, and Sir creeks along the IDR are found to be eroding. Whereas the transects along the Turshian (one of the IR mouth), Khar, Nar, and Wari creek-banks showed a mixed sign of accretion and erosion. The highest rates of erosion are found at the transects along the banks of creeks in the IR East zone of IDR. IR West zone is protected with the dense mangrove canopy (visually verified from the comparison of the corresponding Landsat images used in this study), whereas the presence of medium and sparse mangrove canopy on the eastern side of the IR East zone has exposed it to the intense mechanical action of the Arabian Sea waves alongshore, particularly during the SW monsoon period. Moreover, there are no rivers or streams transporting the water and sediments from upstream to the coast, thereby exposing this side of the IDR to high wave action. Reduction in the mangrove forest cover and weakening of the eco-shield provided by the vegetation along with disastrous reduction in the freshwater inflow and sediment supply to the IDR [25] has led to the widening of the creeks and increased SWI [25,26].

Table 4. Statistical summary of the coastline change rates (1989-2018) for all major creeks located in IR West zone and IR East zone.

\begin{tabular}{lccccccccc}
\hline Creek & Min & Max & Mean & Zone & Creek & Min & Max & Mean & Zone \\
\hline Waddi & -15.33 & -0.25 & -8.91 & IR West & Ghara-Chan & -17.36 & -3.01 & -4.01 & IR East \\
Khal & -54.50 & -1.40 & -17.51 & IR West & Khar & -46.21 & 32.17 & -14.98 & IR East \\
Pitiani & -65.46 & -0.85 & -9.48 & IR West & Nar & -53.55 & 21.00 & -13.34 & IR East \\
Dabbo & -46.12 & -26.90 & -15.39 & IR West & Wari & -57.32 & 8.09 & -31.62 & IR East \\
Chhan & -52.35 & -2.14 & -26.82 & IR West & Kajhar & -64.50 & -4.13 & -26.48 & IR East \\
Turshian & -25.28 & 4.61 & -8.13 & IR West & Sir & -34.66 & -8.76 & -3.14 & IR East \\
Khobar & -51.33 & -11.08 & -22.22 & IR West/ & & & & & \\
\hline
\end{tabular}




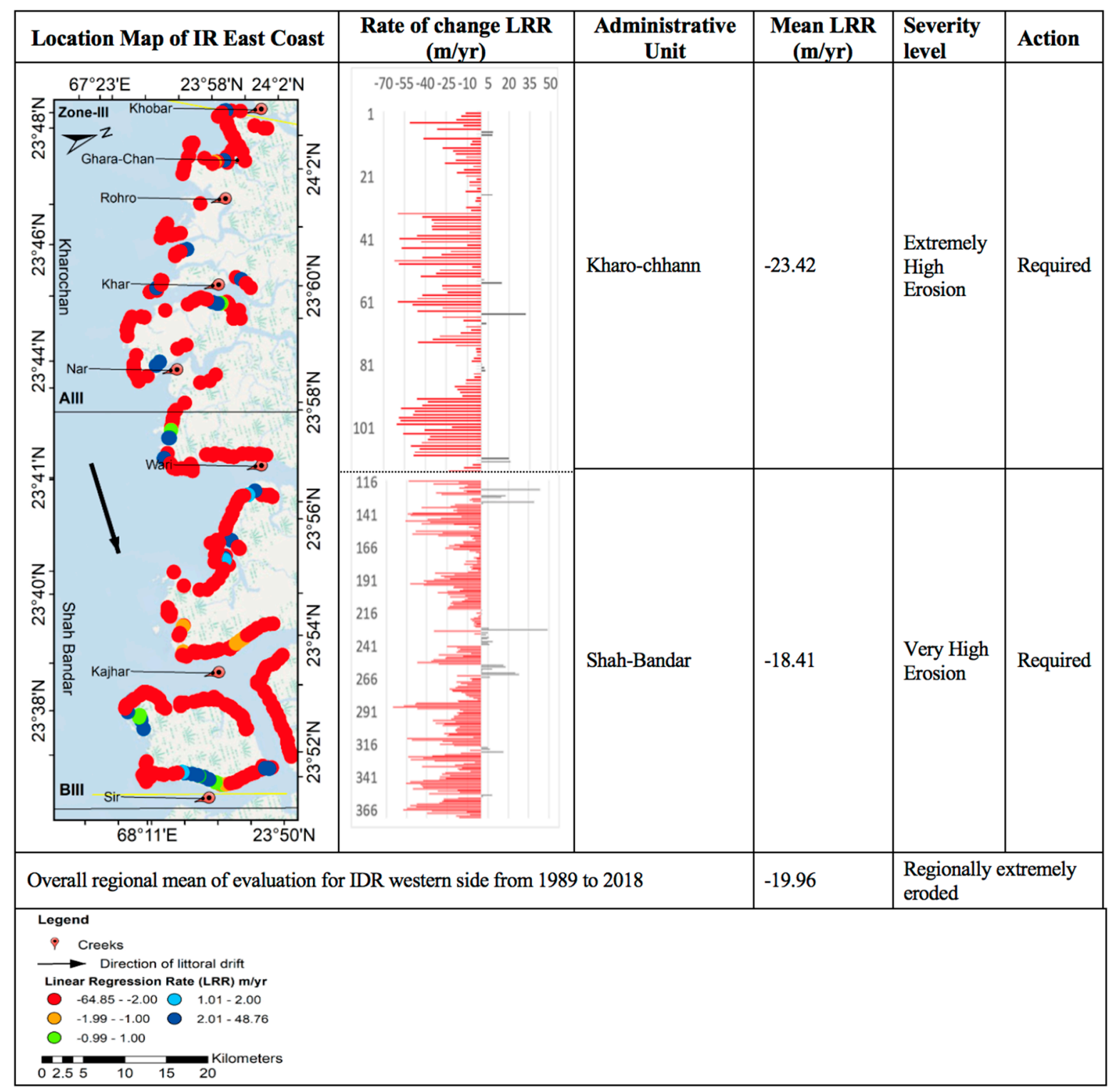

Figure 13. Coastline assessment for IR East zone based on linear regression rate (LRR) statistical method over the period 1989-2018. The description of each column is same as in Figure 9.

\subsection{Analysis of Influencing Factors of Coastline Change}

Coastal sustainability is sensitive to coastal erosion due to its impacts on human-natural systems. Impacts of coastal erosion are likely to increase in the IDR, mainly due to the modification of the fluvial regime of the Indus River caused by terrestrial processes, such as reduction in the flow of freshwater and sediment supply to the IDR, interception of the littoral sediment transport due to human interventions, intensive wave activities, and tidal inundation. As a result, the IR East zone of the IDR seems to have already lost lots of land to open sea. The rate of erosion seems to have significantly increased at most of the transects along the coast, which is also supported by other localized observations from previous studies conducted by the NIO and the WWF-Pakistan. This situation is further aggravated due to the looming climate-change-induced SLR and anthropogenic land-use change.

Considering the severity of the ongoing erosion in the study area, the effects of the climate-change-induced increment in the sea level would be manifold. It is estimated that the global sea level has risen from about $2.5 \mathrm{~mm} / \mathrm{yr}$ in the $1990 \mathrm{~s}$ to about $3.4 \mathrm{~mm} / \mathrm{yr}$ today [64]. Statistical analysis of mean relative sea level at the Karachi tide gauge station for the period 1916-2015, obtained 
from the PSMSL archive, depicted an increasing trend of MSL along the Sindh coast. The Mann-Kendal and Sen's slope estimation test result indicates that the sea level has been rising quite rapidly (i.e., $1.9 \mathrm{~mm} / \mathrm{yr}, p$-value $>95 \%$, Figure 14). This is further complemented by the linear regression analysis of the PSMSL sea level time-series (confidence 75\%) (Figure 14). The increasing trend in the sea level along the Pakistan coastline is higher than that reported by Farah and Meynell [65], Figure 14. This situation can lead to more substantial land encroachment by the seawater, accelerating erosion and resulting in higher investment costs for protective measures. This increasing SLR trend coupled with ongoing coastal erosion during last the three decades could be a potential threat to coastal communities and ecosystems, and the recession might get worse under the future SLR. This situation can result in more coastal areas being subject to inundation [33] if proper measures are not taken. Reports from $\mathrm{NIO}$, Pakistan state that the reclamation, given the climatic and geological sea level rise, has already changed the pattern of energy dissipation along the Clifton beach (subzone-Karachi East), causing inundation of roads in southwest monsoon periods during spring tides [66].

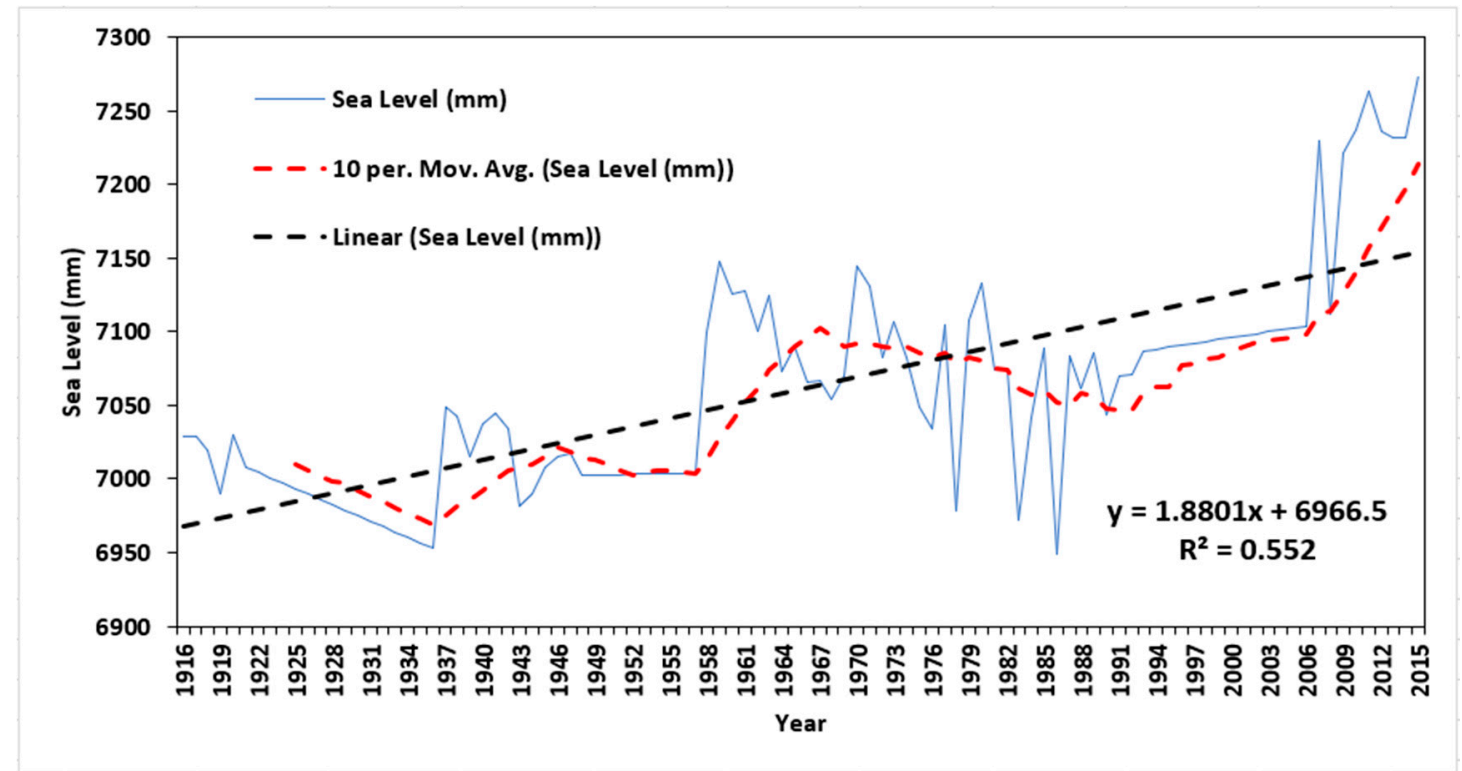

Figure 14. Graphical representation of the mean sea level estimates derived from PSMSL data for Karachi Station during 1916-2015, with the linear trend (black color).

Although the constant evolution of the coastline in the study region is controlled by the multiplicity of terrestrial and marine factors, human interventions are also a major factor affecting the balance of the deltaic region. Concerns have also been raised on the implications of coastal development projects such as Bodha Island City TK's Bodha Islands City Project (https://thomaskramer.com/ tks-bodha-island-city-project/) and Zulfiqarabad (Zulfiqarabad Project-Impact on Environment (https://www.dawn.com/news/702023)) on the coastal dynamics of the study area. Results from this study can be utilized in the planning and design of these projects, considering the erosion in the development process. Based on the evidence on coastal erosion hazard in the region presented in this study, we emphasize that the design and implementation of such new coastal projects in a highly erosive coastal region should consider the multidisciplinary approach in order to ensure the project success and minimize the adverse impacts to the environment and coastal systems.

We observe the erosion to be increasing eastward (Figure 7) while the slope of the land elevation (percent) is decreasing eastward (Figure S3), threatening the eastern parts of Karachi city where one of the major deep seaports of the country, Port Qasim, is located. The flatter the topographic slope, the higher the vulnerability to erosion and SWI. The topographic slope-profile analysis shows that subzone Karachi West in the far west has a steep (upward) gradient $(0 \%-15.5 \%)$, which manifested 
itself as sharp hike in percentage rise in the profile graph as compared to Karachi South and Karachi East subzones ( $0 \%-3.5 \%)$ towards the east (Figure S4). Due to the extreme land-erosion in this region, the fertile lands have already been converted seabed, which is evident in the SPI map, as most of the inland areas are at the same level as the Arabian Sea (Figure S4). This situation is likely to adversely affect the livelihood of the inhabitants. However, further evaluation in this regard is a prerequisite for appropriate decision making. Our study can act as a road map for such further evaluations, as it pin-points the areas of different levels of erosion along the Sindh coast (Figure 9, Figure 11, and Figure 13).

\subsection{Implications for Coastal Sustainability in Pakistan}

Virtually less aggradation or accelerated progradation/recession along with the increasing trend of the SLR has already made the entire IDR as well as the eastern end of the Karachi coastline vulnerable to coastal hazards. As evident from the results, the region is highly susceptible to erosion hazard, which might lead to intense SWI and further inland-flooding. In order to keep the seawater off the coasts along Karachi coastline, the natural coastal barriers such as barrier islands need to be protected/strengthened and other artificial barriers need to be constructed where required. To further reduce risk posed to the humans and environment in the IDR (IR West zone and IR East zone), we suggest nonengineered measures through building-with-nature such as plantation of salt-tolerant mangroves in order to curb the coastal recession and SWI, leading to coastal sustainability in the study area [67]. Restoration of the lost mangroves and conservation of the remaining are integral for stabilizing the coastline [60]. Special seeding techniques might be required for revegetation of the mangroves and their survival. While they reduce coastal erosion due to their soil binding characteristics through their U-shaped prop root system, they also protect the coastal communities from coastal natural hazards (i.e., tropical cyclones and storms), increasing the overall coastal resilience [68]. Current knowledge about the coastline and coastal infrastructure protection seems adequate to derive general guidelines on the role of the coastal vegetation for shielding coastal assets from coastline recession/progradation. However, the effectiveness of the protective role of the vegetation species in combating erosion is site-specific [69]. Adoption of hybrid (mixed engineered-natural) structural measures can also provide increased benefits to coastal systems in the study region. In this way, the present study facilitates promoting risk-informed planning, place-based management, and coastal resilience for long-term sustainability. Taking ecosystem-based measures to reduce the coastal erosion will also assist in achieving sustainable development goals (SDGs) 6, 14, 13, and 15, due to the provisioning of several services from coastal natural systems [70]. Since changes in the coastline morphology alter the flooding hazard, and since long-term coastal management depends on the changing coastline position, simultaneous occurrence of coastal erosion and flood hazard can be jointly studied for comprehensive coastal hazard assessment in Pakistan. The current study provides a basis for such assessments (i.e., the regions where the coastal erosion is higher).

\subsection{Limitations and the Way Forward}

We use the SRTM DEM to analyze the slope at the coast. However, other information derived from DEM, such as coastline curvature and ground subsidence in the coastal regions, can also be used to estimate the contribution of sea level rise to the coastline changes, and thus separate the global climate drivers from the local anthropogenic (coastal infrastructure and use) and other climatic factors (e.g., torrential rainfalls). However, this may require additional resources, computational capabilities, and employment of different, mixed approaches. A preliminary case study on the ground displacement was carried out by Kanwal et al. [56] for Karachi city. This can be done on a large scale and combined with the erosion phenomena for a comprehensive coastline change quantification as well as vulnerability mapping of coastal communities to compound hazards. This could be a potential research question for future studies. Moreover, the shoreline changes along the barrier islands (BIs) could also be evaluated using our framework to further support the coastal sustainability and resilience enhancement, as the 
BIs are known as the important defense against coastal storms and provide multiple services to support socio-ecological systems.

\section{Conclusions}

This study evaluates the spatial heterogeneities in the large-scale morphological changes along the Pakistan coastline on zonal and subzonal (administrative unit smaller than district level) scales during the past three decades (1989-2018). The rates of the coastal erosion are quantified at transect level (total 1232, with a 500-m spacing between transects) and reported as average statistics for each zone and subzone along the Sindh coastline of Pakistan. This multilevel spatial information of coastal erosion from this study is important for coastal planners and decision-makers for effective coastal planning, taking appropriate actions, and adaptation measures to mitigate the erosion process for coastal sustainability, particularly in the regions which are highly vulnerable to coastal erosion. This first-of-its-kind assessment is essential as well as useful for integrated management and planning of the coastal areas in Pakistan. We find that the Sindh coastline, particularly the IDR coastline segment, is highly erosional, which is critical in the context of coastal infrastructure and communities.

Overall, the present trend of coastline retreat will continue to modify the eastern end of Karachi (including Korangi Creek and outlying BIs) due to both human intervention and marine processes if appropriate measures are not taken. Relevant agencies and the policymakers should reinforce the prevention measures on a priority basis (particularly in high erosion areas) so that the inland SWI could be curtailed in the IDR, which is home to thousands of migratory birds, a source of livelihood for millions, and a cultural heritage site. While the results from this study are important for effective coastal planning and implementation of appropriate measures to reduce coastal erosion and the associated risks in Pakistan, the study acts as a road map to scale-down the regions with higher coastal erosion for further in-depth assessments.

Supplementary Materials: The following are available online at http://www.mdpi.com/2072-4292/12/1/8/s1, Figure S1: Spectral responses of coastline configuration. Dotted lines show the location of the instantaneous coastline whereas the solid lines mark the high tide coastline, delineated along the sea-land boundary of Sindh Coast (left to right). Figure S2. Comparison of coastline change rates (m/year) obtained by different statistical methods is presented on right, (a) EPR vs LRR; (b) EPR vs LMS; (c) LRR vs LMS for the overall Sindh coast. Note: EPR, end point rate; LMS, least median of squares; LRR, linear regression rate. Figure S3. Plot of percentage rise measured for the longitudinal profile of Sindh Coast (unit: $\mathrm{km}$ ). Slope (percentage rise) varies from $15.5 \%$ in the west near Ras Mauri to below $0.5 \%$ near Sir Creek. Slope percentage is below $1.1 \%$ for almost the entire IDR region. Figure S4. Slope percentage map of the Sindh coastal region. Black line marks the areas of coastline for which profile graph analysis is done and give below. Table S1: Global EPR and LMS statistics of all the study area coastline change rate (m/yr) during (1989-2018) period.

Author Contributions: This research was supervised by X.D. S.K. designed the research experiments, analyzed the results, and wrote the initial draft. S.K., X.D. and M.S. contributed towards the discussion of results and writing, review, and editing of the manuscript; S.A. provided review of the draft of the manuscript. All authors have read and agreed to the published version of the manuscript.

Funding: This research is funded by the Research Grants Council of Hong Kong Special Administrative Region (PolyU 152043/14E), the Innovative Technology Fund (GHP/006/14SZ), and the National Science Foundation of China (41374013).

Acknowledgments: The authors would like to thank four anonymous reviewers for their insightful and valuable comments which greatly improved the quality of this article.

Conflicts of Interest: The authors declare no conflict of interest.

\section{References}

1. Martínez, C.; Contreras-López, M.; Winckler, P.; Hidalgo, H.; Godoy, E.; Agredano, R. Coastal erosion in central Chile: A new hazard? Ocean Coast. Manag. 2018, 156, 141-155. [CrossRef]

2. Narra, P.; Coelho, C.; Sancho, F. Multicriteria GIS-based estimation of coastal erosion risk: Implementation to Aveiro sandy coast, Portugal. Ocean Coast. Manag. 2019, 178, 104845. [CrossRef]

3. Cazenave, A.; Le Cozannet, G. Sea level rise and its coastal impacts. Earth's Future 2014, 2, 15-34. [CrossRef] 
4. Rahmstorf, S. Rising hazard of storm-surge flooding. Proc. Natl. Acad. Sci.USA 2017, 114, 11806-11808. [CrossRef] [PubMed]

5. Pollard, J.; Spencer, T.; Brooks, S. The interactive relationship between coastal erosion and flood risk. Prog. Phys. Geogr. Earth Environ. 2018, 43, 0309133318794498. [CrossRef]

6. Deepika, B.; Avinash, K.; Jayappa, K. Shoreline change rate estimation and its forecast: Remote sensing, geographical information system and statistics-based approach. Int. J. Environ. Sci. Technol. 2014, 11, 395-416. [CrossRef]

7. UNEP Finance Initiative. The Materiality of Climate Change: How Finance Copes with the Ticking Clock; UNEP Finance Initiative: Geneve, Switzerland, 2009.

8. Ghosh, M.K.; Kumar, L.; Roy, C. Monitoring the coastline change of Hatiya Island in Bangladesh using remote sensing techniques. ISPRS J. Photogramm. Remote Sens. 2015, 101, 137-144. [CrossRef]

9. Klein, R.J.; Nicholls, R.J.; Ragoonaden, S.; Capobianco, M.; Aston, J.; Buckley, E.N. Technological options for adaptation to climate change in coastal zones. J. Coast. Res. 2001, 17, 531-543.

10. Petropoulos, G.P.; Kalivas, D.P.; Griffiths, H.M.; Dimou, P.P. Remote sensing and GIS analysis for mapping spatio-temporal changes of erosion and deposition of two Mediterranean river deltas: The case of the Axios and Aliakmonas rivers, Greece. Int. J. Appl. Earth Obs. Geoinf. 2015, 35, 217-228. [CrossRef]

11. Xu, N. Detecting Coastline Change with All Available Landsat Data over 1986-2015: A Case Study for the State of Texas, USA. Atmosphere 2018, 9, 107. [CrossRef]

12. Griffiths, D.; House, C.; Rangel-Buitrago, N.; Thomas, T. An assessment of areal and transect-based historic shoreline changes in the context of coastal planning. J. Coast. Conserv. 2019, 23, 315-330. [CrossRef]

13. Hein, C.J.; Fallon, A.R.; Rosen, P.; Hoagland, P.; Georgiou, I.Y.; FitzGerald, D.M.; Morris, M.; Baker, S.M.; Marino, G.B.; Fitzsimons, G.; et al. Shoreline dynamics along a developed river mouth barrier island: Multi-decadal cycles of erosion and event-driven mitigation. Front. Earth Sci. 2019, 7, 103. [CrossRef]

14. Mentaschi, L.; Vousdoukas, M.I.; Pekel, J.F.; Voukouvalas, E.; Feyen, L. Global long-term observations of coastal erosion and accretion. Sci. Rep. 2018, 8, 12876. [CrossRef] [PubMed]

15. Oost, A.; Hoekstra, P.; Wiersma, A.; Flemming, B.; Lammerts, E.; Pejrup, M.; Hofstede, J.; Van der Valk, B.; Kiden, P.; Bartholdy, J.; et al. Barrier island management: Lessons from the past and directions for the future. Ocean Coast. Manag. 2012, 68, 18-38. [CrossRef]

16. Rahman, M.M.; Sultana, K.R.; Hoque, M.A. Suitable sites for urban solid waste disposal using GIS approach in Khulna city, Bangladesh. Proc. Pak. Acad. Sci. 2008, 45, 11-22.

17. Frihy, O.; El-Sayed, M. Vulnerability risk assessment and adaptation to climate change induced sea level rise along the Mediterranean coast of Egypt. Mitig. Adapt. Strateg. Glob. Chang. 2013, 18, 1215-1237. [CrossRef]

18. Nassar, K.; Mahmod, W.E.; Fath, H.; Masria, A.; Nadaoka, K.; Negm, A. Shoreline change detection using DSAS technique: Case of North Sinai coast, Egypt. Mar. Georesources Geotechnol. 2019, 37, 81-95. [CrossRef]

19. Kalivas, D.; Kollias, V.; Karantounias, G. A GIS for the assessment of the spatio-temporal changes of the Kotychi Lagoon, Western Peloponnese, Greece. Water Resour. Manag. 2003, 17, 19-36. [CrossRef]

20. Krestenitis, Y.N.; Kombiadou, K.D.; Androulidakis, Y.S. Interannual variability of the physical characteristics of North Thermaikos Gulf (NW Aegean Sea). J. Mar. Syst. 2012, 96, 132-151. [CrossRef]

21. Mallinis, G.; Emmanoloudis, D.; Giannakopoulos, V.; Maris, F.; Koutsias, N. Mapping and interpreting historical land cover/land use changes in a Natura 2000 site using earth observational data: The case of Nestos delta, Greece. Appl. Geogr. 2011, 31, 312-320. [CrossRef]

22. Cui, B.L.; Li, X.Y. Coastline change of the Yellow River estuary and its response to the sediment and runoff (1976-2005). Geomorphology 2011, 127, 32-40. [CrossRef]

23. Li, X.; Damen, M.C. Coastline change detection with satellite remote sensing for environmental management of the Pearl River Estuary, China. J. Mar. Syst. 2010, 82, 54-61. [CrossRef]

24. Giosan, L.; Constantinescu, S.; Clift, P.D.; Tabrez, A.R.; Danish, M.; Inam, A. Recent morphodynamics of the Indus delta shore and shelf. Cont. Shelf Res. 2006, 26, 1668-1684. [CrossRef]

25. Ijaz, M.W.; Mahar, R.B.; Ansari, K.; Siyal, A.A. Optimization of salinity intrusion control through freshwater and tidal inlet modifications for the Indus River Estuary. Estuar. Coast. Shelf Sci. 2019, 224, 51-61. [CrossRef]

26. Ijaz, M.W.; Mahar, R.B.; Siyal, A.A.; Anjum, M.N. Geospatial analysis of creeks evolution in the Indus Delta, Pakistan using multi sensor satellite data. Estuar. Coast. Shelf Sci. 2018, 200, 324-334. [CrossRef]

27. Waqas, M.; Nazeer, M.; Shahzad, M.I.; Zia, I. Spatial and Temporal Variability of Open-Ocean Barrier Islands along the Indus Delta Region. Remote Sens. 2019, 11, 437. [CrossRef] 
28. Fatima, H.; Arsalan, M.H.; Khalid, A.; Marjan, K.; Kumar, M. Spatio-temporal analysis of shoreline changes along Makran Coast using remote sensing and geographical information system. In Proceedings of the Fourth International Conference on Space Science and Technology (ICASE), Islamabad, Pakistan, 2-4 September 2015.

29. Khan, T.M.A.; Razzaq, D.; Chaudhry, Q.U.Z.; Quadir, D.A.; Kabir, A.; Sarker, M.A. Sea level variations and geomorphological changes in the coastal belt of Pakistan. Mar. Geod. 2002, 25, 159-174. [CrossRef]

30. Siddiqui, M.; Maajid, S. Monitoring of geomorphological changes for planning reclamation work in coastal area of Karachi, Pakistan. Adv. Space Res. 2004, 33, 1200-1205. [CrossRef]

31. Khan, T.M.A.; Rabbani, M. Sea Level Monitoring and Study of Sea Level Variations along Pakistna Coast: A Component of Integrated Coastal Zone Management; National Institute of Oceanography: Karachi, Pakistan, 2000.

32. Limmer, D.R.; Henstock, T.J.; Giosan, L.; Ponton, C.; Tabrez, A.R.; Macdonald, D.I.; Clift, P.D. Impacts of sediment supply and local tectonics on clinoform distribution: The seismic stratigraphy of the mid Pleistocene-Holocene Indus Shelf. Mar. Geophys. Res. 2012, 33, 251-267. [CrossRef]

33. Syvitski, J.P.; Kettner, A.J.; Overeem, I.; Hutton, E.W.; Hannon, M.T.; Brakenridge, G.R.; Day, J.; Vörösmarty, C.; Saito, Y.; Giosan, L. Sinking deltas due to human activities. Nat. Geosci. 2009, 2, 681. [CrossRef]

34. Schaap, D.; Schmitt, T. EMODnet High Resolution Seabed Mapping-further developing a high resolution digital bathymetry for European seas. In Proceedings of the EGU General Assembly Conference Abstracts, Vienna, Austria, 7-10 April 2019.

35. Ozturk, D.; Sesli, F.A. Shoreline change analysis of the Kizilirmak Lagoon Series. Ocean Coast. Manag. 2015, 118, 290-308. [CrossRef]

36. Caldwell, P.; Merrifield, M.; Thompson, P. Sea level measured by tide gauges from global oceans-the Joint Archive for Sea Level holdings (NCEI Accession 0019568), Version 5.5, NOAA National Centers for Environmental Information, Dataset. Cent. Environ. Inf. Dataset 2015, 10, V5V40S47W.

37. Toure, S.; Diop, O.; Kpalma, K.; Maiga, A.S. Shoreline Detection using Optical Remote Sensing: A Review. ISPRS Int. J. Geo-Inf. 2019, 8, 75. [CrossRef]

38. Pardo-Pascual, J.; Sánchez-García, E.; Almonacid-Caballer, J.; Palomar-Vázquez, J.; Priego De Los Santos, E.; Fernández-Sarría, A.; Balaguer-Beser, Á. Assessing the accuracy of automatically extracted shorelines on microtidal beaches from Landsat 7, Landsat 8 and Sentinel-2 Imagery. Remote Sens. 2018, 10, 326. [CrossRef]

39. Liu, H.; Wang, L.; Sherman, D.J.; Wu, Q.; Su, H. Algorithmic foundation and software tools for extracting shoreline features from remote sensing imagery and LiDAR data. J. Geogr. Inf. Syst. 2011, 3, 99. [CrossRef]

40. Paravolidakis, V.; Ragia, L.; Moirogiorgou, K.; Zervakis, M. Automatic coastline extraction using edge detection and optimization procedures. Geosciences 2018, 8, 407. [CrossRef]

41. Alesheikh, A.A.; Ghorbanali, A.; Nouri, N. Coastline change detection using remote sensing. Int. J. Environ. Sci. Technol. 2007, 4, 61-66. [CrossRef]

42. Armenio, E.; De Serio, F.; Mossa, M. Analysis of data characterizing tide and current fluxes in coastal basins. Hydrol. Earth Syst. Sci. 2017, 21, 3441. [CrossRef]

43. Nandi, S.; Ghosh, M.; Kundu, A.; Dutta, D.; Baksi, M. Shoreline shifting and its prediction using remote sensing and GIS techniques: A case study of Sagar Island, West Bengal (India). J. Coast. Conserv. 2016, 20, 61-80. [CrossRef]

44. Gornitz, V.M.; Daniels, R.C.; White, T.W.; Birdwell, K.R. The development of a coastal risk assessment database: Vulnerability to sea-level rise in the US Southeast. J. Coast. Res. 1994, 327-338.

45. Mahapatra, M.; Ramakrishnan, R.; Rajawat, A. Coastal vulnerability assessment of Gujarat coast to sea level rise using GIS techniques: A preliminary study. J. Coast. Conserv. 2015, 19, 241-256. [CrossRef]

46. Jenness, J. Topographic Position Index (Tpi_jen. Avx) Extension for ArcView 3. x, v. 1.3 a. Jenness Enterprises. 2006. Available online: http://www.jennessent.com/arcview/tpi (accessed on 18 December 2019).

47. Mann, H.B. Nonparametric tests against trend. Econom. J. Econom. Soc. 1945, 13, 245-259. [CrossRef]

48. Siddig, N.A.; Al-Subhi, A.M.; Alsaafani, M.A. Tide and mean sea level trend in the west coast of the Arabian Gulf from tide gauges and multi-missions satellite altimeter. Oceanologia 2019, 61, 401-411. [CrossRef]

49. Sen, P.K. Estimates of the regression coefficient based on Kendall's tau. J. Am. Stat. Assoc. 1968, 63, 1379-1389. [CrossRef]

50. Taibi, H.; Haddad, M. Estimating trends of the Mediterranean Sea level changes from tide gauge and satellite altimetry data (1993-2015). J. Oceanol. Limnol. 2019, 37, 1-10. [CrossRef] 
51. Dolan, R.; Fenster, M.S.; Holme, S.J. Temporal analysis of shoreline recession and accretion. J. Coast. Res. 1991, 7, 723-744.

52. Douglas, B.C.; Crowell, M. Long-term shoreline position prediction and error propagation. J. Coast. Res. 2000, 16, 145-152.

53. Maiti, S.; Bhattacharya, A.K. Shoreline change analysis and its application to prediction: A remote sensing and statistics based approach. Mar. Geol. 2009, 257, 11-23. [CrossRef]

54. Sengupta, D.; Chen, R.; Meadows, M.E. Building beyond land: An overview of coastal land reclamation in 16 global megacities. Appl. Geogr. 2018, 90, 229-238. [CrossRef]

55. Luijendijk, A.; Hagenaars, G.; Ranasinghe, R.; Baart, F.; Donchyts, G.; Aarninkhof, S. The state of the world's beaches. Sci. Rep. 2018, 8, 6641. [CrossRef]

56. Kanwal, S.; Ding, X.; Zhang, L. Measurement of Vertical Deformation in Karachi Using Multi-Temporal Insar. In Proceedings of the IGARSS 2018-2018 IEEE International Geoscience and Remote Sensing Symposium, Valencia, Spain, 22-27 July 2018; pp. 1395-1398.

57. Hashmi, S.; Ahmad, S. GIS-Based Analysis and Modeling of Coastline Erosion and Accretion along the Coast of Sindh Pakistan. J. Coast. Zone Manag. 2018, 21, 6-9. [CrossRef]

58. Pakistan, I. Mangroves of Pakistan, Status and Management; International Union for Conservation of Nature: Gland, Switzerland, 2005.

59. Mukhtar, I.; Hannan, A. Constrains on mangrove forests and conservation projects in Pakistan. J. Coast. Conserv. 2012, 16, 51-62. [CrossRef]

60. WWF-Pakistan. GIS/RS Based Monitoring of Indus Delta, A Half Century Comparison; WWF: Morges, Switzerland, 2010.

61. Milliman, J.; Haq, B.U. Sea-Level Rise and Coastal Subsidence: Causes, Consequences, and Strategies; Springer Science \& Business Media: Berlin, Germany, 1996; Volume 2.

62. Inam, A.; Clift, P.D.; Giosan, L.; Tabrez, A.R.; Tahir, M.; Rabbani, M.M.; Danish, M. The geographic, geological and oceanographic setting of the Indus River. In Large Rivers: Geomorphology and Management; John Wiley \& Sons, Ltd.: Chichester, UK, 2007; pp. 333-345. [CrossRef]

63. Jelgersma, S.; Van der Zijp, M.; Brinkman, R. Sealevel rise and the coastal lowlands in the developing world. J. Coast. Res. 1993, 9, 958-972.

64. Weeman, K.; Lynch, P. New Study Finds Sea Level Rise Accelerating. 2018. Available online: https://climate. nasa.gov/news/2680/new-study-finds-sea-level-rise-accelerating/ (accessed on 9 September 2019).

65. Farah, A.; Meynell, P. Sea Level Rise Possible Impacts on the Indus Delta, Pakistan; IUCN Korangi Ecosystem Project, Paper. 1992.

66. Muzaffar, M.; Inam, A.; Hashmi, M.; Mehmood, K.; Zia, I.; Imran Hasaney, S. Climate change and role of anthropogenic impact on the stability of Indus deltaic Eco-region. J. Biodivers. Environ. Sci. 2017, 10, 164-176.

67. Van Slobbe, E.; de Vriend, H.J.; Aarninkhof, S.; Lulofs, K.; de Vries, M.; Dircke, P. Building with Nature: In search of resilient storm surge protection strategies. Nat. Hazards 2013, 66, 1461-1480. [CrossRef]

68. Sajjad, M.; Li, Y.; Tang, Z.; Cao, L.; Liu, X. Assessing hazard vulnerability, habitat conservation, and restoration for the enhancement of mainland China's coastal resilience. Earth's Future 2018, 6, 326-338. [CrossRef]

69. Prasetya, G. The role of coastal forests and trees in protecting against coastal erosion. In Proceedings of the Regional Technical Workshop on Coastal Protection in the aftermath of the Indian Ocean tsunami: What role for forest and trees, Khao Lak, Thailand, 28-31 August 2006.

70. Sebesvari, Z.; Foufoula-Georgiou, E.; Harrison, I.; Brondizio, E.; Bucx, T.; Dearing, J.; Ganguly, D.; Ghosh, T.; Goodbred, S.; Hagenlocher, M.; et al. Imperatives for Sustainable Delta Futures. In Brieffor GSDR; Sustainable Development Knowledge Platform: New York, NY, USA, 2016.

(C) 2019 by the authors. Licensee MDPI, Basel, Switzerland. This article is an open access article distributed under the terms and conditions of the Creative Commons Attribution (CC BY) license (http://creativecommons.org/licenses/by/4.0/). 